\title{
1. INTRODUCTION, PRINCIPAL RESULTS, AND EXPLANATORY NOTES, DEEP SEA DRILLING PROJECT LEG 701
}

\author{
Jose Honnorez, Rosenstiel School of Marine and Atmospheric Sciences, University of Miami, Miami, Florida \\ Richard P. Von Herzen, Woods Hole Oceanographic Institution, Woods Hole, Massachusetts \\ and \\ Peter E. Borella, Scripps Institution of Oceanography, La Jolla, California ${ }^{2}$
}

\section{INTRODUCTION}

The Galapagos Spreading Center (GSC) (Fig. 1) is one of the best surveyed regions of the deep-sea floor. Heat-flow measurements (Sclater and Klitgord, 1973; Sclater et al., 1974; Williams et al., 1974; Green et al., 1981), bathymetric surveys (Hey et al., 1977; Lonsdale, 1977; Allmendinger and Riss, 1979), magnetic profiles (Sclater and Klitgord, 1973; Klitgord and Mudie, 1974), and samples from hydrothermal vents (Corliss et al., 1979a, b; Edmond et al., 1979a, b) show that the GSC has been actively spreading and is a site of intense hydrothermal activity. The half-spreading rate, calculated from magnetic anomalies, is about $3.4 \mathrm{~cm} / 10^{3} \mathrm{y}$. and has been steady for about the past $2.0 \mathrm{~m}$.y. The region south of the GSC is characterized by a regularly varying heat-flow pattern, strongly lineated subparallel to the spreading axis.

Although we lacked detailed seismic data on the thickness of the sediment cover in the region south of the GSC, sediment profiles show that it increased rapidly and regularly away from the spreading axis. The rate of increase is consistent with a sedimentation rate of about $5 \mathrm{~cm} / 10^{3} \mathrm{y}$. The seismic reflectors (Fig. 2) found at sub-bottom depths of about 7 and 15 meters over much of the region south of the GSC were tentatively ascribed (Lonsdale, 1977) to ash layers deposited about 140,000 and 300,000 years ago, respectively.

The mounds on the south flank of the Galapagos Spreading Center were first discovered in 1972 during a deep-tow survey of the seafloor in the vicinity of $0^{\circ}$ $30^{\prime} \mathrm{N}, 86^{\circ} 00^{\prime} \mathrm{W}$ (Klitgord and Mudie, 1974). They are conically shaped features, 5 to 25 meters high and 20 to 50 meters in diameter, which protrude above a rather uniform sediment cover about 25 to 35 meters thick over crust that is approximately 0.5 to $0.7 \mathrm{~m}$.y. old. The mounds are frequently aligned in rows parallel or subparallel to the axis of the GSC, sometimes coalescing to form ridges up to $1 \mathrm{~km}$ long, and frequently centered over small displacements of the upper surface of the basement which are inferred to be faults. An extensive physical description of the mounds fields identified by

\footnotetext{
${ }^{1}$ Honnorez, J., Von Herzen, R. P., et al., Init. Repts. DSDP, 70: Washington (U.S. Govt. Printing Office).

2 Present address: Saddleback College, Mission Viejo, California.
}

the deep-tow surveys is given by Lonsdale (1977). As far as is now known, the GSC mounds field is unique.

The association of the mounds field with surrounding high values of geothermal heat flux, combined with a large modulation of the heat flux over the southern GSC flank (Williams et al., 1974), led to the hypothesis that the mounds have a hydrothermal origin. This concept has been strengthened by more recent field work, including detailed observations, measurements, and sampling of some mounds with the submersible Alvin. A detailed visual description of some mounds visited by $\mathrm{Al}$ vin (Williams et al., 1979), chemical and mineralogical analyses of material dredged from mounds (Corliss et al., 1978), and measurement of extremely high geothermal heat fluxes from some mounds (Williams et al., 1979 ) indicate that they are probably formed by chemical precipitation of materials dissolved in seawater when it interacts with the newly formed hot crust.

The recovery of hydrothermal sediments at depth beneath the mounds during a brief period of drilling on Deep Sea Drilling Project (DSDP) Leg 54 provided some evidence suggesting that hydrothermal material may be pervasive over a relatively large region inclusive of the mounds but also incorporating adjacent seafloor presently covered by pelagic sediments (Natland et al., 1979). As a result of the incomplete recovery of sediments at some sites and the poor recovery of basement rocks during Leg 54 , it was suggested that a more carefully planned program be designed to drill a broader range of sites in the Galapagos mounds field. In addition, the recent development of a hydraulic piston-coring technique showed promise in recovering much less disturbed sediments.

\section{OBJECTIVES}

The major objectives of the first part of Leg 70 were to collect data and sediment representative of the hydrothermal mounds and ridges located about $20 \mathrm{~km}$ south of the Galapagos spreading axis. Undisturbed, continuous stratigraphic sequences of sediments and basement rocks from the mounds and from off-mound areas were required to answer the following specific questions:

1) How does the stratigraphy on a mound compare to that off a mound? Similarly, how do the pore water chemistry, physical and paleomagnetic properties, mineralogy, and paleontology of the sediments compare between these two areas? 

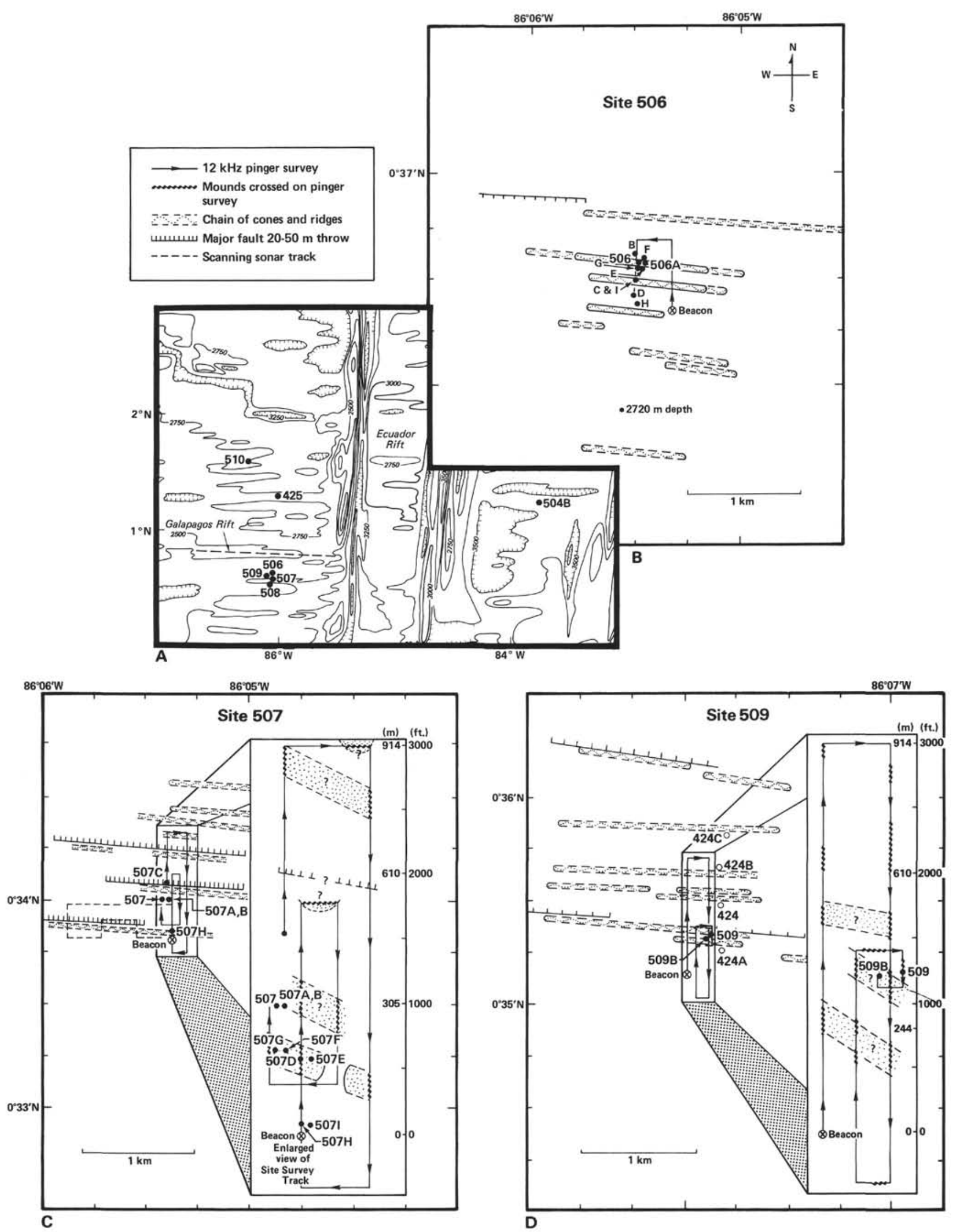

Figure 1. A. General site locality map, Leg 70. B. Detailed mounds site survey, Site 506. C. Detailed mounds site survey, Site 507. D. Detailed mounds site survey, Site 509. 


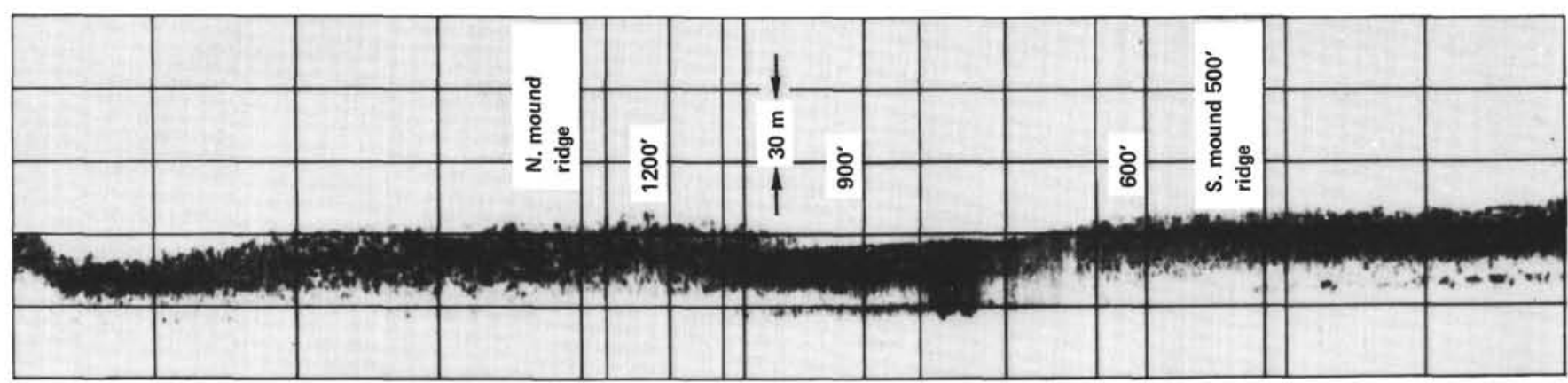

Figure 2. Seismic reflection profile $(3.5 \mathrm{kHz})$ crossing a mounds ridge. (Note the disappearance of the internal reflectors when crossing the mounds.)

2) How does the heat flow measured over the entire sediment column compare to that measured in the upper few meters of sediment? What are the mechanisms of heat transfer?

3) Do the two sub-bottom reflectors observed by Lonsdale (1977) correspond to lithologic boundaries or to physical property changes in sediments? Natland et al. (1979) suggest that these acoustic reflectors represent layers of hydrothermal green clay originally derived from the mounds. What evidence supports or contradicts this suggestion?

4) How variable is sediment stratigraphy of mounds within the same area?

5) Is there a difference between the alteration of basement rock directly beneath the mounds and away from them?

6) Are the chemistry, mineralogy, and physical and magnetic properties of the basement rock affected by the hydrothermal processes which produced the mounds sediments?

7) Are magnetic properties of the basement rocks compatible with the regional magnetic anomaly? Can the area's high magnetism be explained by the rock chemistry and abundancy of opaque minerals in the basalts or are there other contributing factors?

8) Over what period of time were the mounds formed, and are they presently active?

\section{PRINCIPAL RESULTS}

Sediments from the hydrothermal mounds are divided into two categories: (1) nannofossil oozes with varying amounts of foraminifer and siliceous microfossils, and (2) hydrothermal sediments which are subdivided into manganese-oxide crust fragments (mainly todorokite) and green nontronitic clay granules. Preservation of microfossils and ichnofossils in the oozes varies from site to site, with nonmounds sites showing much better preservation than mounds sites. In the hydrothermal sediments, calcareous microfossils are rare, with calcium carbonate content less than $2 \%$. Thin sections of nontronitic granules show calcareous and siliceous microfossils that are wholly or partially replaced by nontronite.

Stratigraphically, the sediment column of each mound can be divided into three units (Figs. 3, 4). From top to bottom they are:
I. Upper pelagic oozes with siliceous microfossil abundance greater than $10 \%$. The lower boundary, defined by the first occurrence of a hydrothermal sediment layer, is very sharp in all but one hole. This unit varies in thickness from 0.3 to 3.0 meters. Some $\mathrm{MnO}$-crust fragments are present in several cores but do not form any definite layer.

II. Interbedded and mixed hydrothermal sediment and pelagic oozes. The hydrothermal sediments compose the majority of Unit II with unit thicknesses ranging from 13 to 28 meters. Nontronitic clay in all but one core is the uppermost hydrothermal layer (the uppermost layer in Hole 509B is a 1.4-meter-thick layer of $\mathrm{MnO}$-crust fragments). Contacts between hydrothermal and pelagic sediments within this unit are gradational.

III. Lower pelagic oozes, primarily foraminifer nannofossil oozes, have a thickness from 7 to 17 meters. The upper contact is gradational with the overlying nontronitic clay. Abundant nontronite mottles are found immediately beneath the last cohesive layer of nontronite and disappear downward toward the basement.

Preliminary findings indicate that hydrothermal sediments are thickest at the mounds sites, thinning rapidly away from the mounds, and that they are not continuous layers that persist over large areas. The stratigraphy also indicates that deposition of hydrothermal sediments commenced after a 7- to 17-meter thick pelagic sediment blanket had been deposited. Hydrothermal activity appears to be intermittent or at least variable in intensity with time. On the mounds, siliceous fossil content in the pelagic oozes drops off below $5 \%$ about 8 meters below the sediment/seawater interface. No drop-off is present in the nonmounds sites. This, along with the reduced thickness of pelagic sediments on the mounds, suggests that dissolution of microfossils may be associated with hydrothermal activity. However, preliminary geochemical calculations indicate that a major nonbiogenic supply of silica is needed to form the hydrothermal smectite,

Preliminary measurements using the Long Core Spinner show that no paleomagnetic reversals occur in the mounds sediments. The most interesting observation relating to natural remanent magnetism (NRM) is that whenever a lithologic boundary occurs, no significant differences are observed between remanence direction and intensity in the pelagic oozes and hydrothermal 


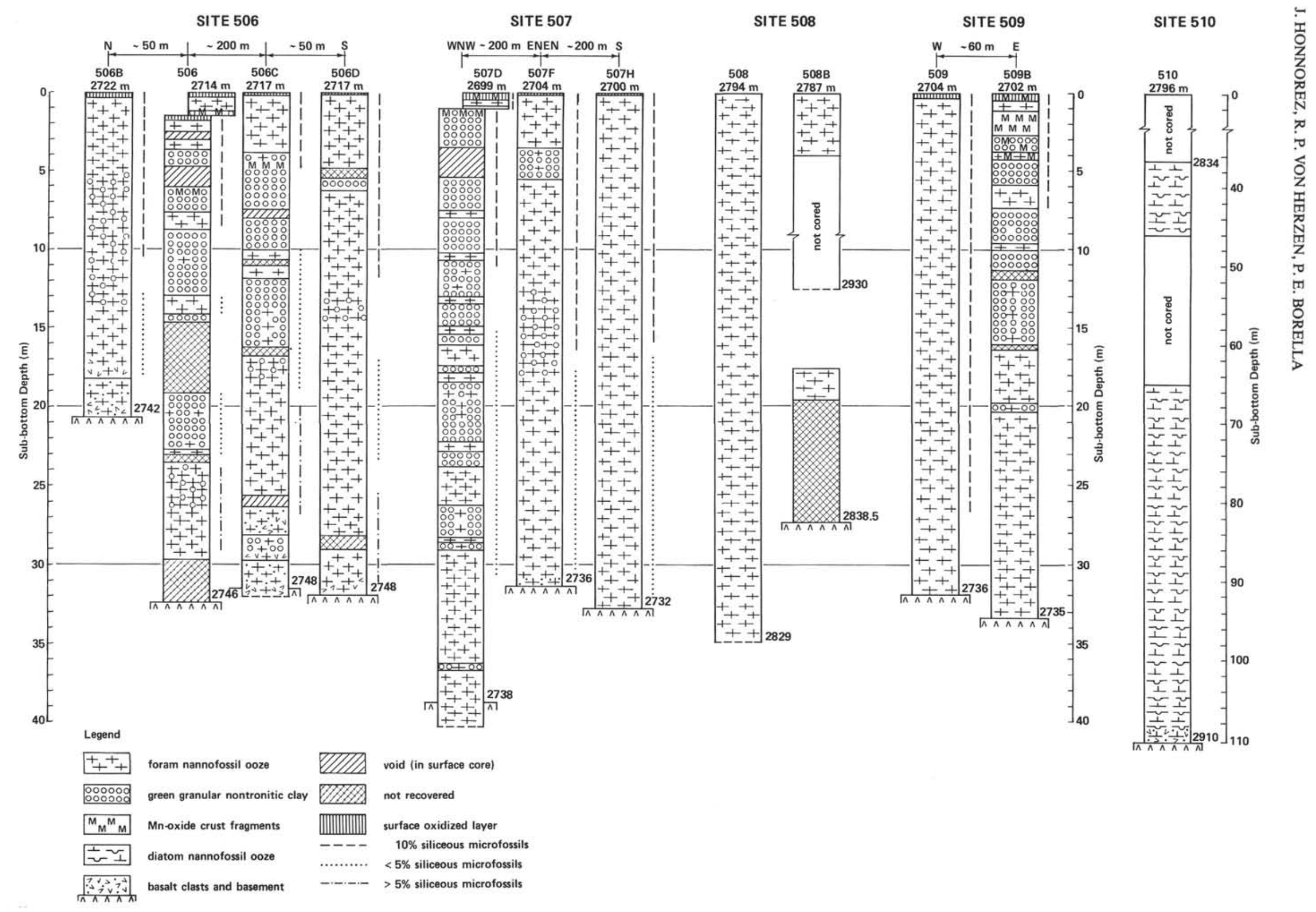

Figure 3. Stratigraphic summary-HPC, Leg 70. 


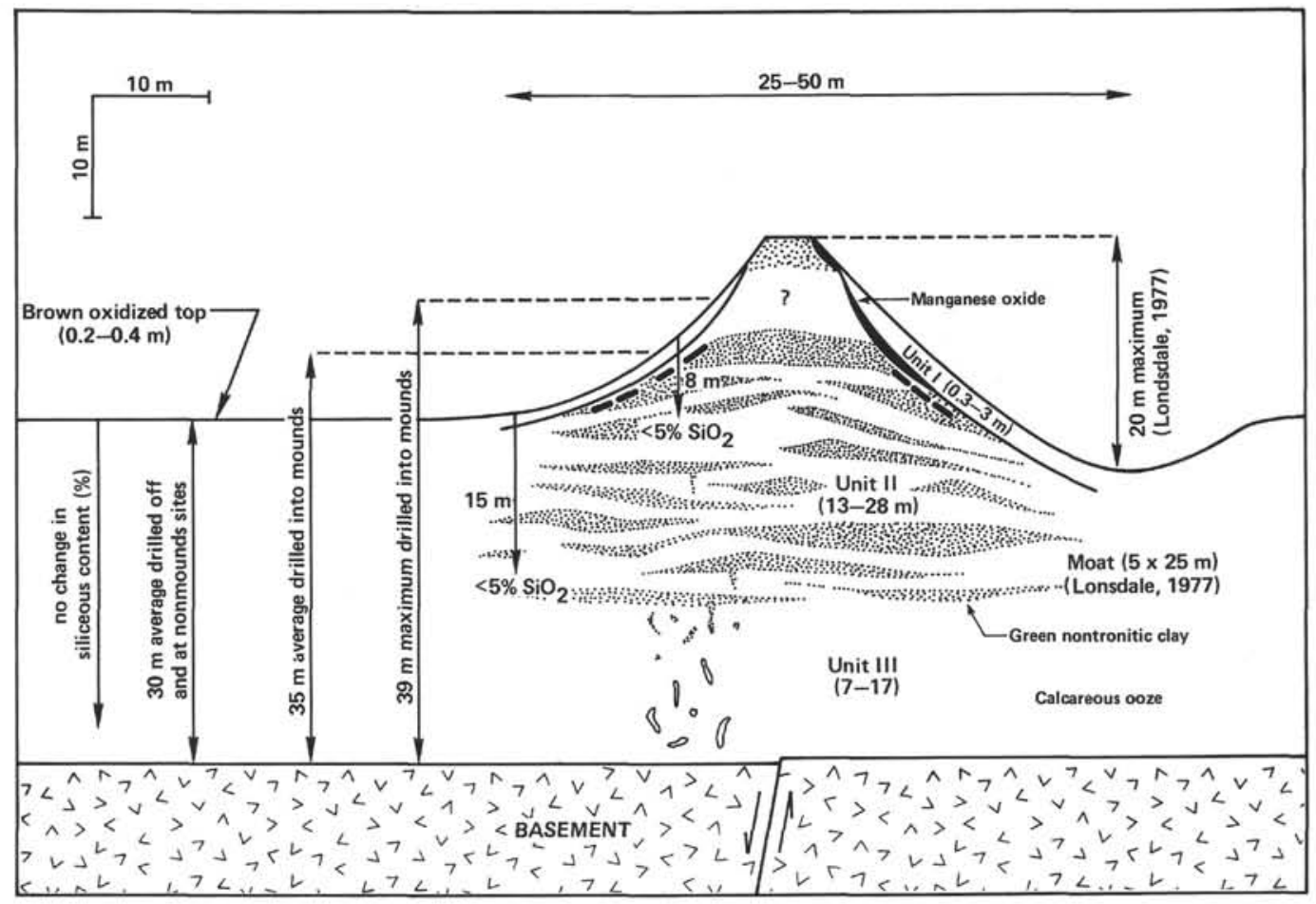

Figure 4. Idealized diagram of the internal structure and dimensions of a mound. (Reprinted from the Geol. Soc. Am. Bull., Pt. 1, Vol. 92.)

Table 1. Average values of physical constants of sediments from Galapagos Spreading Center, Leg 70.

\begin{tabular}{lccccc}
\hline & $\begin{array}{c}\text { Wet-Bulk } \\
\text { Density } \\
\left(\mathrm{g} / \mathrm{cm}^{3}\right)\end{array}$ & $\begin{array}{c}\text { Grain } \\
\text { Density } \\
\left(\mathrm{g} / \mathrm{cm}^{3}\right)\end{array}$ & $\begin{array}{c}\text { Porosity } \\
(\%)\end{array}$ & $\begin{array}{c}\text { Sonic } \\
\text { Velocity } \\
(\mathrm{km} / \mathrm{s})\end{array}$ & $\begin{array}{c}\text { Thermal } \\
\text { Conductivity } \\
(\mathrm{W} / \mathrm{m} \cdot \mathrm{K})\end{array}$ \\
\hline Manganese oxides & $1.98 \pm 0.26$ & $3.75 \pm 0.36$ & $69.0 \pm 10.3$ & $2.22 \pm 0.07$ & - \\
Granular green clays & $1.46 \pm 0.19$ & $3.13 \pm 0.23$ & $77.9 \pm 8.5$ & $1.61 \pm 0.09$ & $0.80 \pm 0.07$ \\
Nongranular green clays & $1.20 \pm 0.10$ & $2.74 \pm 0.28$ & $89.8 \pm 5.4$ & $1.55 \pm 0.02$ & $0.78 \pm 0.06$ \\
Pelagic sediments & $1.32 \pm 0.09$ & $2.65 \pm 0.08$ & $82.2 \pm 4.2$ & $1.51 \pm 0.02$ & $0.91 \pm 0.08$ \\
\hline
\end{tabular}

sediments. If some of the hydrothermal sediments are produced by chemical transformation of pelagic oozes, these results may suggest that the magnetic oxides were not mobilized or significantly affected by the hydrothermal reactions.

Physical property measurements on the sediments are summarized in Table 1. Differences in physical properties among the sediments cause irregular depth gradients, especially where hydrothermal and pelagic sediments occur together. There are no abrupt physical property variations with depth in the sediments to account for possible seismic reflectors (Lonsdale, 1977).

Pore water analyses along with heat-flow and thermal-conductivity measurements of the mounds' sediments confirm the hypothesis that the mounds are the foci of localized hydrothermal activity. These convective discharges are responsible for the high heat-flow values (up to $700 \mathrm{mWm}^{-2}$ ) and the relative enrichment of $\mathrm{Ca}$ and depletion of $\mathrm{Mg}, \mathrm{Si}$, and $\mathrm{NH}_{3}$ when sites of high heat flow are compared to those of low heat flow. Geochemical and geophysical data suggest that there is rapid upwelling of solutions from the basement through the mounds, slow upwelling off the mounds, and recharge at nonmounds sites.
The basement rocks of the mounds are ferrobasalts and seem to lack any unusual alteration features. They are 0.54 to 0.85 m.y. old. The alteration patterns and mineralogy are very similar to those of young crust material found at other nonmounds localities. No evidence of hydrothermal alteration was observed. The basalt can be divided into two groups related to age:

1) Young crust basalts (Sites 506-508) are fine- to medium-grained aphyric to sparsely plagioclase phyric basalt. Textures range from glassy to ophitic/intergranular. Titanomagnetite is the dominant opaque phase.

2) Intermediate age basalts recovered from Site 510 are fine- to medium-grained moderately plagioclase, sparsely olivine phyric basalts. Titanomagnetite is less abundant in comparison to the young crust basalts. The paleomagnetic properties are very consistent with an inversion of a negative anomaly source made up by a 500-m-thick basalt layer. These high amplitude magnetic anomalies (approximately $21-22 \times 10^{3}$ gauss), relative to other oceanic basalts, are however about onehalf that of zero-age samples from the Galapagos Spreading Center 19 to $26 \mathrm{~km}$ north of Sites 506-508 (Anderson et al., 1975; Levi, this volume). This may be the result of low-temperature oxidation of the primary titanomagnetites (Irving et al., 1970; Johnson and Atwater, 1977). Lesser amounts of titanomagnetites at Site 510 , where $J_{N R M}$ is less than one-third of the younger sites, support this hypothesis and suggest that Site 510 may be just outside the zone of high amplitude magnetic anomalies. Site 425 basalts are the first recovery of the youngest nonferrobasalts directly adjacent to the ferrobasalts which are characteristic of the Galapagos Spreading Center. 
Physical property measurements on the basement rocks show that on the average GSC basalts have a high grain density and low porosity, and as a result a high wet-bulk density as compared to other oceanic basalts. This increase is tentatively attributed to the high iron content.

\section{MOUNDS FORMATION}

Just as others have previously deduced (Klitgord and Mudie, 1974; Lonsdale, 1977; Corliss et al., 1978; Williams et al., 1979), most of these observations have led us to models which explain mounds formation as a result of precipitation of materials from hydrothermal solutions. However, the unique results of our mounds drilling allow us to narrow the range of specific models.

The presence of pelagic sediments as the most superficial mound layer in all of the DSDP cores would imply that hydrothermal activity has ceased. However, this inference is inconsistent with the following: (1) observations by the submersible that hydrothermal products outcrop at the top of the mounds; (2) the high water temperature measured above the mounds, and (3) the shipboard heat-flow measurements and pore-water analyses indicating rapid upwelling of hydrothermal solutions through the mounds. The apparent contradiction is removed if one assumes that the cores were drilled into the flanks and not into the tops of hydrothermally active mounds.

The nonlinear chemical and thermal gradients also strongly suggest that the mounds are actively forming, rather than being relics of some past local geological event. The high heat flow surrounding the region of the mounds and the even higher values on some of the mounds themselves are consistent with a model of upward-moving hydrothermal solutions.

Our model, then, is one of hydrothermal fluids slowly percolating upward through the sediments and interacting chemically with both sediments and seawater to form mounds by the precipitation of hydrothermal minerals. Mounds are formed above localized regions of the crust with high permeability, where the rubble-like thin lava flows of the basement have been further disrupted by faulting.

The restricted distribution of the hydrothermal products and their interfingering with the pelagic sediments of the mounds (Fig. 4), when combined with the evidence for gradational contacts, indicate that intimate interactions between these two materials occurred beneath the water/sediment interface. The direct discharge of hydrothermal solutions into seawater to form the hydrothermal products by precipitation onto the seafloor, as suggested by Hekinian et al. (1978), seems less likely.

It has been proposed that the nontronitic clay mineral formed first (Bischoff, 1972; Rateev et al., 1980) and that this mineral was later progressively replaced by celadonite or vice versa (Hoffert et al., 1978, 1980). Alternatively, iron could precipitate first in pelagic sediments as amorphous $\mathrm{Fe}$-oxyhydroxides from upward diffusing hydrothermal waters, which then further react with the hydrothermal solutions and biogenic silica to form nontronite.
Considerations of charge balance put useful constraints on how iron in the hydrothermal solutions is converted into $\mathrm{Fe}$-oxyhydroxides or nontronite in the mounds. On the one hand, the iron in ascending solutions is most probably reduced, $\mathrm{Fe}^{3+}$ being insoluble except in very acidic solutions. On the other hand, the iron in $\mathrm{Fe}$-oxyhydroxides or nontronite is completely or mainly trivalent, and $\mathrm{Fe}_{4} \mathrm{Si}_{8} \mathrm{O}_{20}(\mathrm{OH})_{4}$ can be taken as a simple formula for this clay mineral. Therefore, an essential component of nontronite formation is the oxidation of $\mathrm{Fe}^{2+}$. Three oxidants are capable of energetically oxidizing ferrous iron: $\mathrm{O}_{2}, \mathrm{NO}_{3}{ }^{-}$, and $\mathrm{MnO}_{2}$. The overall reaction involving $\mathrm{O}_{2}$ is:

$4 \mathrm{Fe}^{2+}+8 \mathrm{SiO}_{2}+6 \mathrm{H}_{2} \mathrm{O}+6 \mathrm{O}_{2}-\mathrm{Fe}_{4} \mathrm{Si}_{8} \mathrm{O}_{20}(\mathrm{OH})_{4}+8 \mathrm{H}^{+}$

One mechanism for oxidation is the downward diffusion of $\mathrm{O}_{2}$ and/or $\mathrm{NO}_{3}-$ from the bottom waters through the sediment/water interface. For normal diffusion rates, calculations show that nontronite would have to be forming within a few centimeters of the interface to match the sedimentation rate in this region $\left(\approx 5 \mathrm{~cm} / 10^{3}\right.$ y.). The calculation for reasonable concentrations of oxidants in the bottom waters $\left[\left(\mathrm{O}_{2}\right)=10^{-4} \mathrm{M},\left(\mathrm{NO}_{3}{ }^{-}\right)\right.$ $\left.=0.4 \times 10^{-4} \mathrm{M}\right]$ gives required water fluxes of a few tens of centimeters per year, rates which are quite consistent with measured temperature and chemical gradients. An important feature of reaction (1) is that protons $\left(\mathrm{H}^{+}\right)$are produced which can drive calcite dissolution according to the following equation:

$$
\begin{aligned}
4 \mathrm{Fe}^{2+}+8 \mathrm{SiO}_{2}+\mathrm{O}_{2}+6 \mathrm{H}_{2} \mathrm{O}+8 \mathrm{CaCO}_{3} & -\mathrm{Fe}_{4} \mathrm{Si}_{8} \mathrm{O}_{20}(\mathrm{OH})_{4} \\
& +8 \mathrm{Ca}^{2+}+8 \mathrm{HCO}_{3}^{-}
\end{aligned}
$$

Similar reactions can be formulated for $\mathrm{NO}_{3}{ }^{-}$and $\mathrm{MnO}_{2}$ reduction. The generation of acid during nontronite formation presumably drives the dissolution of $\mathrm{CaCO}_{3}$ and helps account for the purity of the nontronite in the sediments. If nontronite is formed by oxygen reduction, for example, 8 moles of $\mathrm{CaCO}_{3}$ (with a volume of $1,500 \mathrm{~cm}^{3}$ ) are dissolved per mole of nontronite produced (with a volume of $900 \mathrm{~cm}^{3}$ ), resulting in a $40 \%$ volume reduction of the sediment column. This might explain the presence of the moats around some mounds. One can show that if the $\mathrm{Fe}^{3+} / \mathrm{Fe}^{2+}$ ratio in the precipitated nontronite were less than 3 , the absence of $\mathrm{CaCO}_{3}$ in the nontronite layer would be ascribed to another mechanism, such as the winnowing of biogenic debris after its having fallen on the hard Mnoxide crust of the mounds. However, we know that nontronites essentially contain $\mathrm{Fe}^{3+}$ occupying octahedral sites.

The lack of biogenic $\mathrm{SiO}_{2}$ in the mounds sediments may also be a result of dissolution by ascending solutions. Calculations show that pore waters ascending at rates of a few tens of centimeters per year can dissolve all of the silica at the present rate of accumulation if they acquire silica in solution at a concentration of a few hundred $\mu \mathrm{M} l^{-1}$. It is not clear yet whether the siliceous 
and/or carbonate microfossils are being dissolved or replaced by the nontronite.

The evidence, uniquely provided by Leg 70 drilling, that $\mathrm{MnO}_{2}$ generally overlies nontronite suggests a mechanism for nontronite formation by the replacement of $\mathrm{MnO}_{2}$ accompanied by $\mathrm{CaCO}_{3}$ dissolution, according to the following equation:

$$
\begin{aligned}
4 \mathrm{Fe}^{2+}+8 \mathrm{SiO}_{2} & +2 \mathrm{MnO}_{2}^{+}+4 \mathrm{H}_{2} \mathrm{O}+4 \mathrm{CaCO}_{3}-\mathrm{Fe}_{4} \mathrm{SiO}_{20}(\mathrm{OH})_{4} \\
+ & 2 \mathrm{Mn}^{2+}+4 \mathrm{Ca}^{2+}+4 \mathrm{HCO}_{3}{ }^{-}
\end{aligned}
$$

A similar equation can be developed for the reduction of $\mathrm{NO}_{3}{ }^{-}$. This could be accomplished by either continuous or sudden (batch) replacement of $\mathrm{MnO}_{2}$ by nontronite. The continuous upward growth of nontronite at the expense of $\mathrm{MnO}_{2}$ would account for the scarcity of $\mathrm{MnO}_{2}$ crusts at depth in the mounds sediments. The interlayering of pure nontronite and pelagic sediments may be better explained by batch replacement.

Our observations can be explained in terms of either a steady-state process or episodic process with hydrothermal minerals forming during brief intervals, perhaps once every $10^{4}$ to $10^{5}$ years. We infer from the presence of 10 meters or so of basal carbonate ooze at the mounds sites that hydrothermal minerals began to form at least about 200,000 years after the onset of sediment accumulation. If the formation of mounds is a steadystate process in the Galapagos region, then incipient mounds may be found as close as $6 \mathrm{~km}$ from the spreading center, assuming a half spreading rate of $3.4 \mathrm{~cm} / \mathrm{y}$. (Klitgord and Mudie, 1974). According to Klitgord and Mudie (1974), little if any sediment is deposited within 2 to $7 \mathrm{~km}$ of the Galapagos Spreading Center. Therefore, the age discrepancy between the oldest sediment and the underlying basement should range from 60,000 to 200,000 years. However, the region out to about $15 \mathrm{~km}$ from the spreading center is predominantly characterized by relatively low heat flow, which may have caused a delay in the initiation of mounds formation until 400,000 years or so. Moreover, if one assumes that nontronite formed by reaction with and replacement of the pelagic sediments, then the hydrothermal process started after the pelagic sediments in both Units II and III had been deposited (Fig. 4), that is about 400,000 years ago. In the later case, the age of the hydrothermal material of the mounds should range from the present to a few tens of thousands of years.

Very high gradients in physical properties of sediments occur within 30 to 50 meters of the basalt basement at Sites 506 to 510 . It is interesting that this is also the sediment thickness where the mounds are presently found, and this similarity may not be coincidental. The large gradients in physical properties may be interpreted as being the result of rapid dewatering or some other process which reduces the porosity of the earliest sediments deposited on young ocean crust. Since proximity to basement seems to be the controlling factor, it seems logical to associate this effect with hydrothermal circulation. Sediment thickness of 30 to 50 meters may be the critical thickness at which hydrothermal solutions can effectively interact with the sediments in the Galapagos area (Williams et al., 1979). For younger crust with thinner sediments, the hydrothermal fluids may exchange with seawater primarily through permeable rock outcrops, bypassing the less permeable sediments. On older crust, the exchange of hydrothermal waters with seawater may be effectively suppressed by the thicker sediments. In any case, although the exact cause of the gradients has not been determined, the association of mounds formation with sediment thicknesses comparable to those in which large physical properties gradients occur suggests a common origin for both.

From shipboard measurements of physical properties on disturbed sediments from the mounds, Hekinian et al. (1978) concluded that the green clay sediments were denser and had higher in situ(?) sonic velocities than did associated pelagic oozes. The two reflectors that Lonsdale (1977) attributed to ash layers were interpreted by Natland et al. (1979) as corresponding to the impedance contrast between the top and bottom of the green smectite layer and the pelagic sediments. As a consequence, this "hydrothermal" layer was believed to extend continuously throughout the area of the mounds and into the entire heat-flow region beyond. We found just one ash layer in each of three out of twelve holes. Thus any regional extension on nontronitic clay layers, or a drastic change in the physical properties of the sediments, must be excluded as cause of the reflectors. We are unable, at this stage, to suggest any alternative explanation.

\section{OPERATIONS}

The D/V Glomar Challenger departed Panama on 11 November 1979, heading to the Galapagos hydrothermal mounds area (Fig. 4). The approach to each of the mounds sites required good navigation to place us within previously mapped mounds fields (Lonsdale, 1977) with an accuracy of better than 0.5 miles. The speed of the Glomar Challenger was adjusted to receive a satellite fix a few miles before coming across the sites. In addition, a depth contour chart of a multibeam echo-sounding survey of the Galapagos region was on board so we were able to follow recognizable topography under the track of the vessel as recorded by the ship's acoustic depth sounders $(3.5$ and $12 \mathrm{kHz})$. This strategy worked well and always enabled us to drop the beacon within a few tenths of a nautical mile of the desired position.

Detailed site surveys were made in the mounds fields (Fig. 4). With a $12-\mathrm{kHz}$ pinger attached to the drill string approximately 100 meters above the hydraulic piston corer (HPC) bit, the mounds appeared as diffuse echoes elevated 5 to 10 meters above the seafloor, roughly 100 meters wide from PDR recordings; internal reflectors beneath them disappeared (Fig. 2). With a change in the drill string equipment from HPC to conventional rotary drilling (CRD), a sonar scanning tool was also used to help locate the mounds. It gave a broader view of the mounds ridges than had the $12-\mathrm{kHz}$ drill string pinger, confirming nearly east-west lineations of mounds ridges in the fields presented by Lonsdale (1977) and showing individual mounds peaks comprising the ridges. 
The HPC was used quite successfully at all sites. Recovery was high (61-99\%), with most of the cores undisturbed and showing detailed stratigraphy. A useful by-product of the deployment of the $12-\mathrm{kHz}$ drill string pinger is the ability to place the drill bit within 1 to 2 meters of the seafloor for the first coring attempt, thereby ensuring recovery of "mud line" in the first core.

Drilling conditions in the basement in the Galapagos area were poor, with torquing and jamming during rotation. Penetration and recovery of basalts were unsatisfactory, probably because of the fractured nature of the rocks. A detailed operations summary of Leg 70 in the Galapagos region is presented in Table 2.

We proceeded to the Costa Rica rift area and reentered Site 504B for an attempt at deep penetration into basement.

\section{EXPLANATORY NOTES}

\section{Responsibilities of Authorship}

Site summaries are coauthored by the entire scientific party; ultimate responsibility lies with the two co-chief scientists. Site summaries are organized into the following sections, with authors names in parentheses.

Site Summary Sheet

Principal Results

Background (Honnorez)

Objectives (Honnorez and Von Herzen)

Operations (Von Herzen and Borella)

Sediment Lithology and Stratigraphy (Barrett, Borella, Migdisov, and Moorby)

Biostratigraphy (Jones)

X-Ray Diffraction Analysis (Moorby and Borella)

Sedimentation Rates (Borella)

Seismic Stratigraphy (Von Herzen)

Pore Water Geochemistry (Bender)

Physical Properties (Karato and Becker)

Heat Flow (Becker and Von Herzen)

Sediment Paleomagnetism (Levi)

Igneous Petrology and Lithostratigraphy (Hubberten, Laverne, Schrader, and Honnorez)

Basement Alteration (Hubberten, Laverne, Schrader, and Honnorez)

Basement Physical Properties (Karato)

Basement Paleomagnetism (Levi)

Conclusions (Honnorez and Von Herzen)

The interpretations of individual authors have been retained in the sections for which they were responsible. As a result, differences between interpretations in a particular section and those in the conclusions sometimes occur.

\section{Shipboard Scientific Procedures}

\section{Numbering of Sites, Holes, Cores, and Samples}

DSDP drill sites are numbered consecutively from the first site drilled by Glomar Challenger in 1968. Site numbers are slightly different from hole numbers. A site number refers to one or more holes drilled while the ship was positioned over one acoustic beacon. These holes can be located within a radius as great as 900 meters from the beacon. Several holes may be drilled at a single site by pulling the drill pipe above the seafloor (out of one hole), moving the ship 100 meters or more, and then drilling another hole.

The first (or only) hole at a site takes the site number. A letter suffix distinguishes each additional hole at the same site. For example, the first hole takes only the site number, the second takes the site number with suffix $\mathrm{A}$, the third takes the site number with suffix B, and so forth. It is important for sampling purposes to distinguish holes drilled at a site, since sediments or rocks recovered from different holes usually do not come from equivalent positions in the stratigraphic column.

The cored interval is measured in meters below the seafloor. The depth interval of a core is the range between the depth below seafloor where coring began and the depth where coring ended. Each coring interval is generally 9.5 meters long, which is the nominal length of a core barrel; however, the coring interval may be shorter or sometimes slightly longer. "Cored intervals" are not necessarily adjacent to each other, but may be separated by "drilled intervals." In soft sediment, the drill string can be "washed ahead," with the core barrel in place though not recovering sediment, by pumping water down the pipe at high pressure to wash the sediment out of the way of the bit and up the space between the drill pipe and the wall of the hole. If thin hard rock layers are present, then it is possible to get "spotty" sampling of these resistant layers within the washed interval and thus to have a cored interval greater than 9.5 meters.

Cores taken from a hole are numbered serially from the top of the hole downward. Core numbers and their associated cored interval in meters below the seafloor are normally unique for a hole; however, problems may arise if an interval is cored twice. When this occurs, the core number is assigned a suffix, such as " $\mathrm{S}$ " for supplementary ${ }^{3}$.

Full recovery for a single core is normally 9.28 meters of sediment or rock in a plastic liner (6.6 cm I.D.), plus about a 0.2 -meter long sample (without a plastic liner) in the core catcher. The core catcher is a device at the bottom of the core barrel which prevents the cored sample from sliding out when the barrel is being retrieved from the hole. The core is then cut into $1.5-\mathrm{m}$-long sections and numbered serially from the top of the core (Fig. 5). When we obtain full recovery, the sections are numbered from 1 through 7 , with the last section shorter than 1.5 meters. The core-catcher sample is placed below the last section when the core is described and labeled core catcher (CC); it is treated as a separate section. In special cases, some cores may also have a letter designation: for example, $\mathrm{H}$ equals "washed interval but recovered material in the core barrel."

For partial recovery, the original stratigraphic position of the material in the cored interval is unknown. If the recovered material is contiguous, we assign the top

\footnotetext{
${ }^{3}$ Note that this designation has been used on previous legs as a prefix to the core number for sidewall core samples.
} 
Table 2. Operations summary.

\begin{tabular}{|c|c|c|c|c|c|}
\hline Date & Hole & $\begin{array}{l}\text { Offset Coordinates } \\
\text { (ft, from beacon) }\end{array}$ & $\begin{array}{l}\text { Purpose of } \\
\text { Drilling }\end{array}$ & $\begin{array}{l}\text { On-site } \\
\text { Survey }\end{array}$ & Comments \\
\hline \multicolumn{6}{|c|}{ Site $506\left(0^{\circ} 36.588^{\prime} \mathrm{N}, 8^{\circ} 05.491^{\prime} \mathrm{W}\right)$} \\
\hline \multirow[t]{3}{*}{$1 / 14 / 79$} & 506 & $1350 \mathrm{~N}, 1000 \mathrm{~W}$ & $\begin{array}{l}\text { HPC-mounds } \\
\text { sediment }\end{array}$ & $12 \mathrm{kHz}$ pinger & \\
\hline & $506 \mathrm{~A}$ & $1350 \mathrm{~N}, 950 \mathrm{~W}$ & $\begin{array}{l}\text { In situ temp. and } \\
\text { pore-water }\end{array}$ & & \\
\hline & $506 \mathrm{~B}$ & $1500 \mathrm{~N}, 950 \mathrm{~W}$ & $\begin{array}{l}\text { HPC - north edge of } \\
\text { mounds ridge }\end{array}$ & & \\
\hline \multirow[t]{2}{*}{$1 / 16 / 79$} & $506 \mathrm{C}$ & $550 \mathrm{~N}, 950 \mathrm{~W}$ & $\begin{array}{l}\text { HPC-mounds } \\
\text { sediments }\end{array}$ & & \\
\hline & $506 \mathrm{D}$ & $300 \mathrm{~N}, 950 \mathrm{~W}$ & $\begin{array}{l}\text { HPC - sediments } \\
\text { south of mounds } \\
\text { ridge }\end{array}$ & & \\
\hline \multirow[t]{5}{*}{$1 / 17 / 79$} & $506 \mathrm{E}$ & Same as $506 \mathrm{~A}$ & $\begin{array}{l}\text { In situ temp. and } \\
\text { pore water }\end{array}$ & $\begin{array}{l}10 \text { in. }^{3} \text { air gun } \\
3.5 \mathrm{kHz} \text { sonar } \\
\text { scanning }\end{array}$ & $\begin{array}{l}3.5 \mathrm{kHz} \text { useful tool for } \\
\text { locating basement and } \\
\text { internal sediment reflectors }\end{array}$ \\
\hline & $506 \mathrm{~F}$ & $1600 \mathrm{~N}, 950 \mathrm{~W}$ & Same as above & & \\
\hline & $506 \mathrm{G}$ & Same as 506A & $\begin{array}{l}\text { CRD_basement } \\
\text { drilling }\end{array}$ & & $\begin{array}{l}18 \mathrm{hr} \text {. of rotary drilling with } \\
\text { minimal success at sample } \\
\text { recovery. Drilling }\end{array}$ \\
\hline & $506 \mathrm{H}$ & Same as 506D & Same as above & & conditions poor \\
\hline & 5061 & Same as $506 \mathrm{E}$ & Same as above & & \\
\hline \multicolumn{6}{|c|}{ Site $507\left(0^{\circ} 34.0^{\prime} \mathrm{N}, 86^{\circ} 05.4^{\prime} \mathrm{W}\right)$} \\
\hline \multirow[t]{3}{*}{$1 / 19 / 79$} & 507 & $1100 \mathrm{~N}, 200 \mathrm{~W}$ & $\begin{array}{l}\text { In situ temp. and } \\
\text { pore water }\end{array}$ & Side scanning sonar & $\begin{array}{l}\text { Beacon dropped over approx. } \\
30 \mathrm{~m} \text { sediment }\end{array}$ \\
\hline & 507A & $1100 \mathrm{~N}, 150 \mathrm{~W}$ & Same as above & & \\
\hline & $507 \mathrm{~B}$ & Same as above & $\begin{array}{l}\text { CRD basement } \\
\text { drilling }\end{array}$ & & $\begin{array}{l}7 \mathrm{~m} \text { penetration } \\
0.6 \mathrm{~m} \text { recovery } \\
\text { hole abandoned }\end{array}$ \\
\hline $1 / 20 / 79$ & $507 \mathrm{C}$ & $1550 \mathrm{~N}, 9 \mathrm{~W}$ & Same as above & & $\begin{array}{l}5 \mathrm{~m} \text { penetration } \\
0.2 \mathrm{~m} \text { recovery }\end{array}$ \\
\hline \multirow[t]{2}{*}{$1 / 21 / 79$} & 507D & $600 \mathrm{~N}, 0 \mathrm{~W}$ & $\begin{array}{l}\text { HPC-mounds } \\
\text { sediments }\end{array}$ & $12 \mathrm{kHz}$ pinger & $\begin{array}{l}\text { Five-hour survey, chain of } \\
\text { mounds appeared less } \\
\text { continuous and less } \\
\text { prominent than } 506\end{array}$ \\
\hline & $507 \mathrm{E}$ & $600,50 \mathrm{E}$ & $\begin{array}{l}\text { In situ temp. and } \\
\text { pore water }\end{array}$ & & \\
\hline \multirow[t]{3}{*}{$1 / 22 / 79$} & $507 \mathrm{~F}$ & $650 \mathrm{~N}, 150 \mathrm{~W}$ & $\begin{array}{l}\text { HPC-mound } \\
\text { sediments }\end{array}$ & & Mounds/flank \\
\hline & 507G & $650 \mathrm{~N}, 200 \mathrm{~W}$ & $\begin{array}{l}\text { In situ temp. and } \\
\text { pore water }\end{array}$ & & \\
\hline & $507 \mathrm{H}$ & $100 \mathrm{~N}, 0 \mathrm{~W}$ & HPC-sediments & & Off mound \\
\hline $1 / 23 / 79$ & 5071 & $100^{\prime} \mathrm{N}, 50^{\prime} \mathrm{E}$ & $\begin{array}{l}\text { In situ temp. and } \\
\text { pore water }\end{array}$ & & \\
\hline \multicolumn{6}{|c|}{ Site $508\left(0^{\circ} 32.06^{\prime} \mathrm{N}, 8^{\circ} 06.45^{\prime} \mathrm{W}\right)$} \\
\hline $1 / 24 / 79$ & $\begin{array}{l}508 \\
508 \mathrm{~A}\end{array}$ & $\begin{array}{l}0 \mathrm{~N}, 0 \mathrm{E} \\
0 \mathrm{~N}, 0 \mathrm{E}\end{array}$ & $\begin{array}{l}\text { HPC-sediments } \\
\text { In situ temp. and } \\
\text { pore water }\end{array}$ & None & Nonmounds, low heat flow \\
\hline $1 / 25 / 79$ & 508B & $2720 \mathrm{~S}, 1270 \mathrm{~W}$ & $\begin{array}{l}\text { CRD-basement } \\
\text { drilling }\end{array}$ & & $\begin{array}{l}\text { Abandoned; poor drilling } \\
\text { conditions }\end{array}$ \\
\hline \multirow[t]{3}{*}{$1 / 26 / 79$} & $508 \mathrm{C}$ & $2670 \mathrm{~S}, 1270 \mathrm{~W}$ & $\begin{array}{l}\text { CRD-sediment } \\
\text { above basement }\end{array}$ & & $\begin{array}{l}\text { Semi-indurated sediment } \\
\text { which was washed } \\
\text { through at 508B }\end{array}$ \\
\hline & 508D & $0 \mathrm{~N}, 0 \mathrm{E}$ & $\begin{array}{l}\text { In situ temp. and } \\
\text { pore water }\end{array}$ & & \\
\hline & 508E & $0 \mathrm{~N}, 0 \mathrm{E}$ & Same as above & & \\
\hline \multicolumn{6}{|c|}{ Site $509\left(0^{\circ} 35.34^{\prime} \mathrm{N}, 86^{\circ} 07.89^{\prime} \mathrm{W}\right)$} \\
\hline $1 / 27 / 79$ & 509 & $1250 \mathrm{~N}, 600 \mathrm{E}$ & $\begin{array}{l}\text { HPC - sediments } \\
\text { mounds flank }\end{array}$ & $12 \mathrm{kHz}$ pinger & $\begin{array}{l}\text { Five-hour detailed survey } \\
\text { to map mounds }\end{array}$ \\
\hline \multirow[t]{4}{*}{$1 / 28 / 79$} & $509 \mathrm{~A}$ & $1250 \mathrm{~N}, 600 \mathrm{E}$ & $\begin{array}{l}\text { In situ temp. and } \\
\text { pore water }\end{array}$ & & \\
\hline & $509 \mathrm{~B}$ & $1200 \mathrm{~N}, 400 \mathrm{E}$ & $\begin{array}{l}\text { HPC - mounds } \\
\text { sediments }\end{array}$ & & \\
\hline & $509 \mathrm{C}$ & $1200 \mathrm{~N}, 400 \mathrm{E}$ & $\begin{array}{l}\text { In situ temp. and } \\
\text { pore water }\end{array}$ & & \\
\hline & 509D & $1400 \mathrm{~N}, 600 \mathrm{E}$ & Same as above & & \\
\hline \multicolumn{6}{|c|}{ Site $510\left(1^{\circ} 36.79^{\prime} \mathrm{N}, 86^{\circ} 24.60^{\prime} \mathrm{N}\right)$} \\
\hline $1 / 29 / 79$ & 510 & $0 \mathrm{~N}, 0 \mathrm{E}$ & $\begin{array}{l}\text { CRD-basement } \\
\text { drilling. Spot } \\
\text { sediment coring } \\
\text { and in situ temp. } \\
\text { and pore water } \\
\text { measurements } \\
\text { above basement }\end{array}$ & None & $\begin{array}{l}9.3 \mathrm{hr} \text {. hard-rock drilling } \\
\text { penetrating } 19 \mathrm{~m} \text { with } \\
5.2 \mathrm{~m} \text { basalt recovered; } \\
\text { abandoned because of } \\
\text { poor drilling conditions }\end{array}$ \\
\hline \multicolumn{6}{|c|}{ Site $504 \mathrm{~B}\left(1^{\circ} 13.6^{\prime} \mathrm{N}, 8^{\circ} 43.8^{\prime} \mathrm{W}\right)$} \\
\hline $12 / 3 / 79$ & $504 \mathrm{~B}$ & & $\begin{array}{l}\text { CRD_basement } \\
\text { drilling }\end{array}$ & & $\begin{array}{l}\text { Re-entry of hole occupied } \\
\text { by Leg } 69\end{array}$ \\
\hline
\end{tabular}

Note: $\mathrm{HPC}=$ hydraulic piston corer; $\mathrm{CRD}=$ conventional rotary drilling; site location coordinates are given for beacon . 

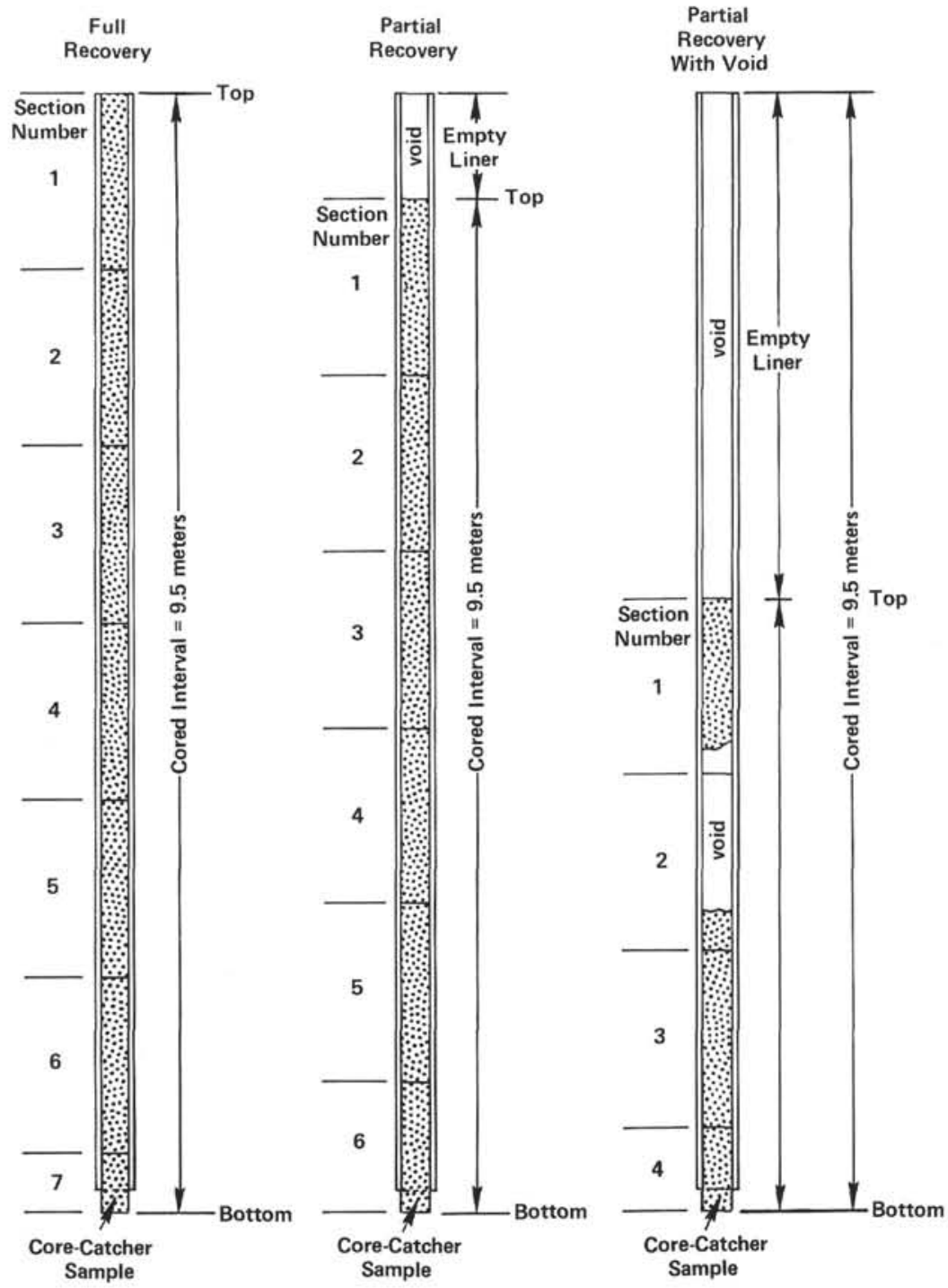

Figure 5. Labeling of core sections for various kinds of recovery.

of this material to the top of the cored interval and number sections serially from the top beginning with Section 1 (Fig. 5) ${ }^{4}$. There are as many sections as needed to accommodate the length of the recovered material. For example, 4 meters of material are divided into three sections, two upper sections each 1.5 meters long and a final lower section only 1.0 meter in length. If the material recovered is not contiguous, as determined by the shipboard scientists, then sections are divided and numbered serially as with contiguous material, and gaps are labeled as voids for sediments (Fig. 5) or marked by spacers for igneous rocks (see Igneous Rocks section).

Samples are designated by centimeter distances from the top of each section to the top and bottom of the sample in that section. A full identification number for a sample consists of the following information:

Leg

Site

${ }^{4}$ This technique differs from the labeling systems used on Legs 1 through 45 , which had a designation called "zero section" but did not have a "number 7 section."
Hole

Core number

Section

Interval in centimeters from the top of section

For example, a sample identification number of 70 506B-4-3, 12-14 cm is interpreted as follows: $12-14 \mathrm{~cm}$ designates a sample taken $12-14 \mathrm{~cm}$ from the top of Section 3 of Core 4 from the third hole (B) drilled at Site 506 during Leg 70 . A sample from the core catcher of this core would be designated 70-506B-4,CC.

When making a sample request please refer to a specific interval within a section of a core. DSDP now has sample listings from each leg listed on microfiche cards with assigned absolute sample depths in meters. For requests write to the DSDP Information Handling Group.

\section{Handling of Cores}

A core is normally cut into 1.5 -meter sections, sealed, and labeled, then brought into the core laboratory for processing. Long core-spinner magnetism measurements, 
gas analyses, thermal conductivity measurements, and continuous wet-bulk density determinations using the Gamma-Ray Attenuation Porosity Evaluator (GRAPE) were made before splitting sections.

The cores were then split longitudinally into "working"' and "archive"' halves. Samples were taken from the "working", half, including those for determination of grain-size distribution, mineralogy by X-ray diffraction, sonic velocity by the Hamilton Frame method, wet-bulk density by a static GRAPE technique, water content by gravimetric analysis, carbon-carbonate analysis, calcium carbonate percentage (carbonate bomb), geochemical analysis, paleontological studies, and others.

Smear slides (thin sections for lithified sedimentary and igneous rocks) from each major and most minor lithologies were prepared and examined microscopically. The archive half was then described and photographed. Physical disturbance by the drill bit, color, texture, structure, and composition of the various lithologies were noted on standard core description forms. All prime data are routinely microfilmed and some are digitized for computer retrieval.

After the cores were sampled and described, they were maintained in cold storage on board Glomar Challenger until they could be transferred to the DSDP repository. Core sections of sediments removed for organic geochemistry study were frozen immediately on board ship and kept frozen. All Leg 70 cores and frozen cores are presently stored at the DSDP west coast repository (Scripps Institution of Oceanography).

When the cores arrive at the repository, Tom E. Chase, U.S.G.S., Menlo Park, with his recently invented microfilm enlargement and retrieval unit (or 'contraption'), routinely photographs all hydraulic piston cores on 35-mm continuous flow microfilm. (These films are available at the termination of a one-year proprietary hold.) The microfilm system is discussed in the appendix to this chapter by Chase et al., and appendix Plates 1 and 2 (in the back pocket of the volume) illustrate, respectively, the "Underway Seismic Reflection Profiles-Leg 70"' as they are recorded on the system, and "Selected Hydraulic Piston Cores-Leg 70."

\section{Hydraulic Piston Corer}

On Leg 70 the Serocki-Storms-Cameron hydraulic piston corer (HPC) was used successfully to recover undisturbed sediments at Sites 506 to 509. Recovery averaged $93 \%$, which was attributed to the low shear strength of the sediments and calm seas. If one discounts the first hole, 506, recovery averaged a remarkable $98 \%$. HPC holes are not assigned a special letter designation.

The principles of the operation of the HPC are presented in Figure 6. The HPC is located within the lowermost part of the drill string and is flush with the base of the drill bit before it is fired. Once fired the corer ideally penetrates 4.4 meters into the underlying sediment. The full extension of the HPC to this length is reflected on the rig floor by complete pressure bleed-off following the shot. After penetration into the sediment, the HPC is pulled up 4.4 meters to a position within the lower- most part of the drill string. The whole drill string is then raised to a point where a drill string tool joint appears at the level of the rig floor. The raised interval ranges from 0.0 to 9.5 meters (the length of one joint of drill pipe). Thus a total open hole beneath the drill bit can be as long as $9.5+4.4$ meters, or 13.9 meters. The drill string is then separated at the tool joint, and the inner core barrel with the 4.4 meters of sediment is pulled to the rig floor on the sandline.

After removal of the core, the inner core barrel of the HPC is reloaded and returned to the base of the drill string. The HPC drill bit then washes down through the sediment interval just previously cored, but only for a distance of approximately 3.4 meters. The last meter of lowering is done without washing. The base of the drill string is now at the desired level for the next HPC shot.

The presence of an open hole below the drill string during the time the HPC inner core barrel is retrieved and reloaded and the fact that the drill string washes down 3.4 meters and is pushed the last meter begins to explain why the upper parts of many of the hydraulic piston cores are contaminated with material previously cored and disturbed. The raising of the entire drill string as much as 9.5 meters also explains why a mud-line core may be taken twice.

\section{SEDIMENTS AND SEDIMENTARY ROCKS}

\section{Core Description}

\section{Drilling Disturbance}

Recovered rocks, and particularly the soft sediments, may be extremely disturbed. This mechanical disturbance is the result of the coring technique, which uses a large $25-\mathrm{cm}$ diameter bit with a small $6.0-\mathrm{cm}$ diameter opening for the core sample. The following disturbance categories are used for soft and firm sediment:

1) Slightly deformed: bedding contacts are slightly bent.

2) Moderately deformed: bedding contacts have undergone extreme bowing. Firm sediment is fractured.

3) Very deformed: bedding is completely disturbed or homogenized by drilling, sometimes showing symmetrical diapir-like structure. Firm zones may have relic "drill biscuits"' in a breccia or homogeneous matrix.

4) Soupy: water saturated intervals which have lost all aspects of original bedding.

These categories are coded on the core description form in the column headed "drilling disturbance" (Fig. 7).

\section{Sedimentary Structures}

In the soft, and even in some harder sedimentary cores, it may be extremely difficult to distinguish between natural structures and those created by the coring process. Thus, the description of sedimentary structures was optional. Locations and types of these structures appear as graphic symbols in the column headed "sedimentary structures" on the standard core description form (Fig. 7) and the expanded hydraulic piston core description form (Fig. 8). Figures 9 and 10 give the keys to these symbols. 


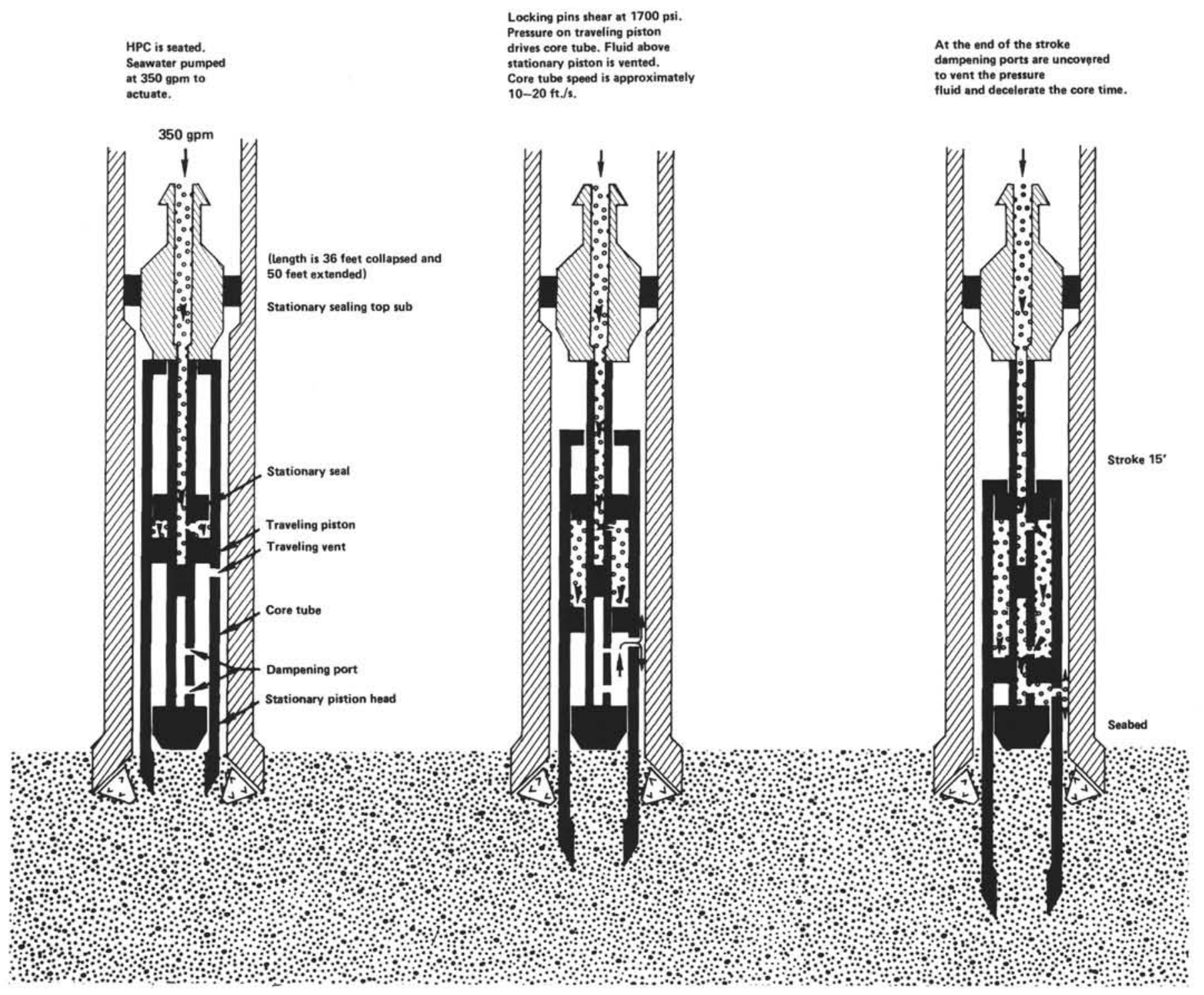

Figure 6. Operational sequence of DSDP hydraulic piston corer.

Bioturbation, where distinguishable, is noted on the graphic column. A summary of the most common biogenic sedimentary structures (ichnofossils) observed in DSDP cores is given in Figure 11.

\section{Color}

Colors of the geologic material are determined with a Munsell or Geological Society of America Rock Color Chart. Colors were determined immediately after the cores were split and while wet.

\section{Lithology}

The graphic column presented on the standard core description form is based on the lithologies and represented by a single pattern or by a grouping of two or more symbols. The symbols in a grouping correspond to end members of sediment constituents, such as clay or nannofossil ooze. The symbol for the terrigenous con- stituent appears on the right-hand side of the column, the symbol for the biogenic constituent(s) on the lefthand side of the column. The abundance of any component approximately equals the percentage of the width of the graphic column its symbol occupies. For example the left $20 \%$ of the column may have a diatom ooze symbol while the right $80 \%$ of the column may have a silty-clay symbol, indicating sediment composed of $80 \%$ mud and $20 \%$ diatoms.

Because of the difference in the length-to-width ratio between the actual sediment core and the graphic lithologic column, it is not possible to reproduce structures as they appeared in the core; they become highly flattened and distorted. The same is true for rock fragments or pebbles in the cores. As a result, the locations of pebbles are shown by a solid square and the depth of small "patches" of ash or other lithologic changes are given by a triangular inset of the appropriate symbol on the 


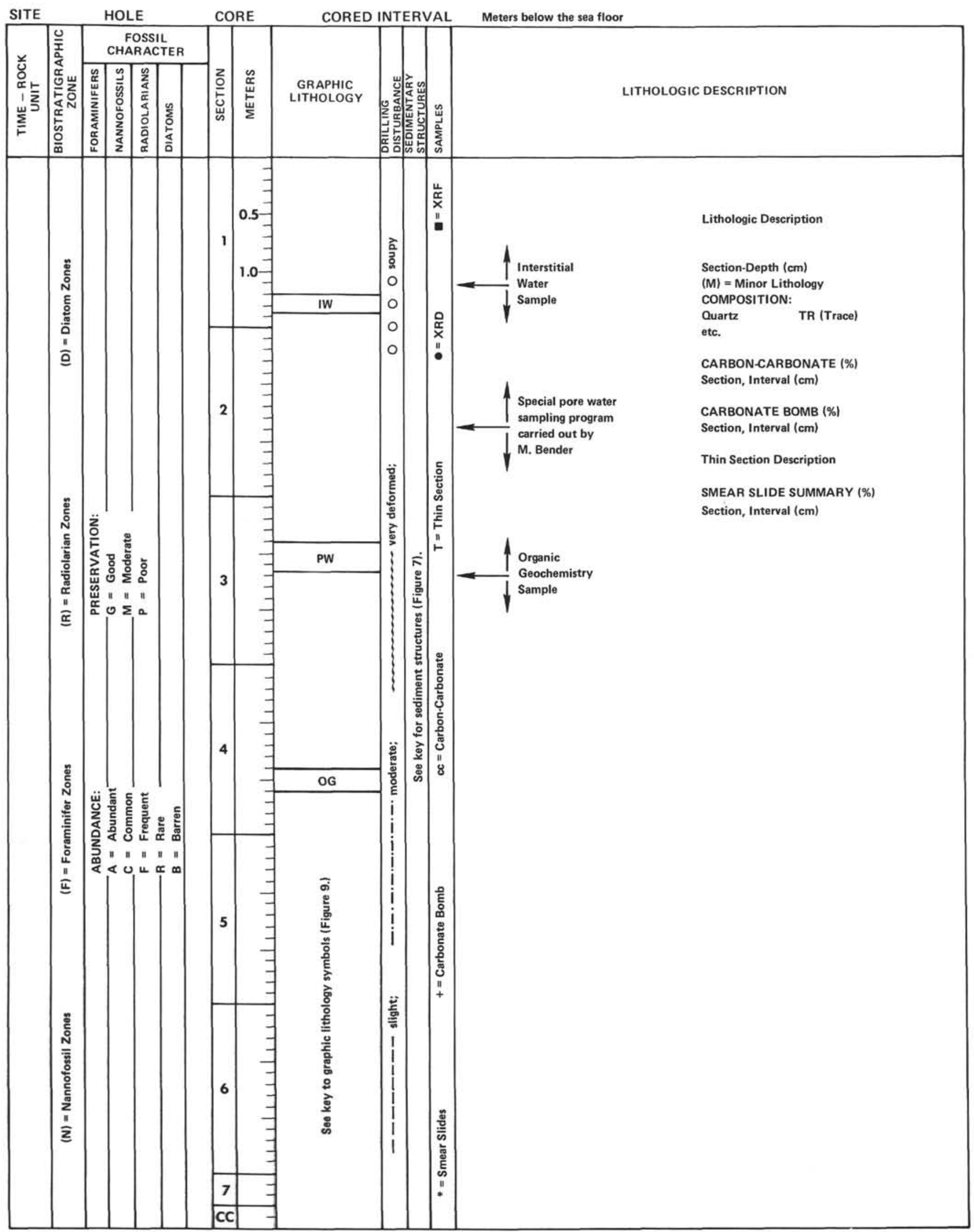

Figure 7. Standard core description form for sediments. 


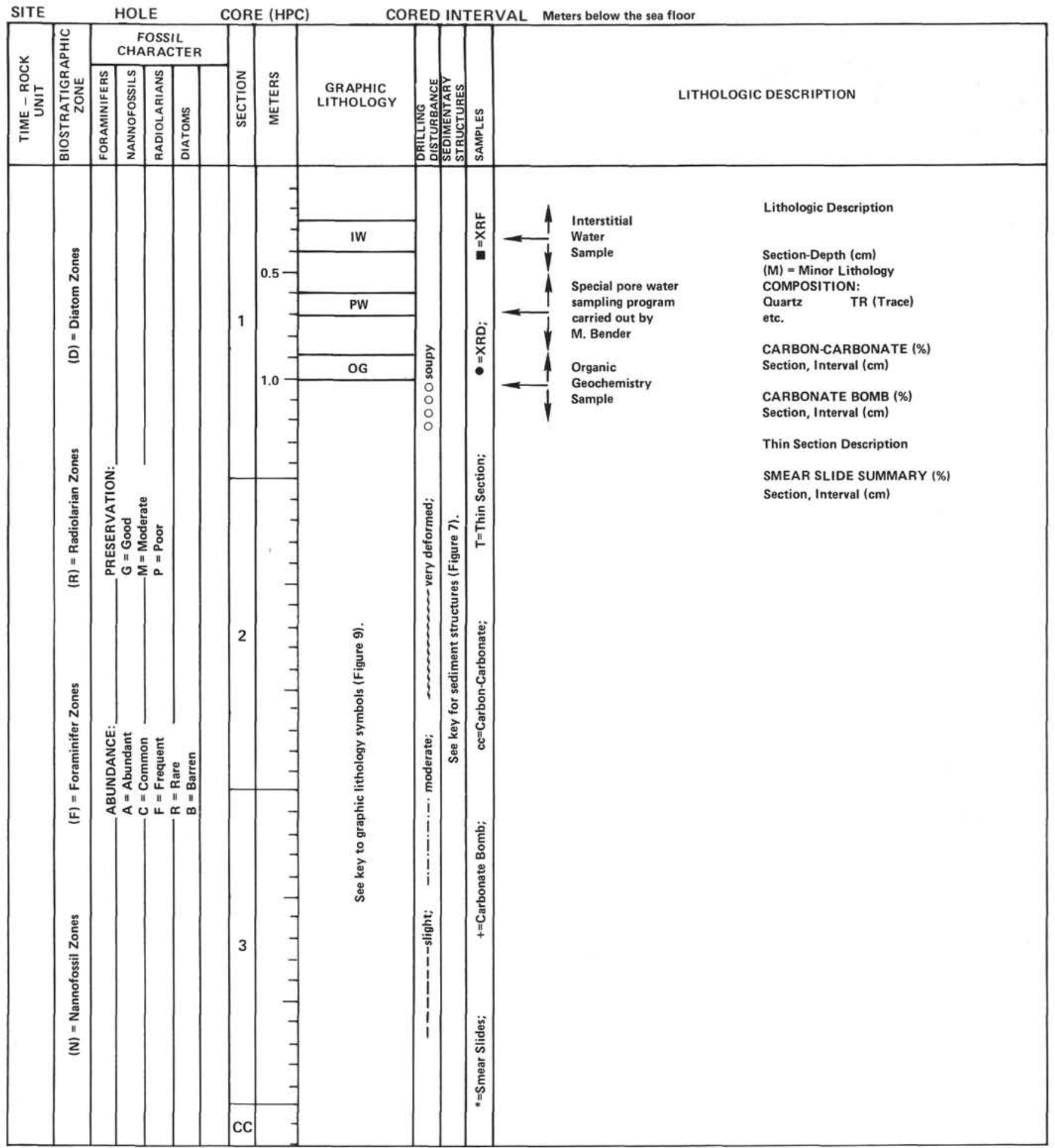

Figure 8. Hydraulic piston core description form.

right side of the lithologic column (Fig. 10). This convention applies only to lithologies which do not extend across the entire core.

Format, style, and terminology of the descriptive portion of the core description forms (Figs. 7 and 8) are not controlled by the "mandatory graphic lithologic column scheme," beyond the minimal name assignment which is derived from the lithologic classification (to be described). Colors and additional information such as structures and texture are included in the text portion of the core description.

Smear slide (or thin section) compositions, carbonate content $\left(\% \mathrm{CaCO}_{3}\right)$, and organic carbon content determined on board ship are listed below the core descrip- 
Recommended

Symbol

\begin{tabular}{|c|c|}
\hline $\mathrm{mm}$ & Current ripples \\
\hline$\mu$ & Micro-cross-laminae (including climbing ripples) \\
\hline 春 & Parallel bedding \\
\hline$\omega$ & Wavy bedding \\
\hline & Flaser bedding \\
\hline 00 & Lenticular bedding \\
\hline & Cross-stratification \\
\hline ᄂ & Slump blocks or slump folds \\
\hline & Load casts \\
\hline 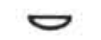 & Scour \\
\hline$\bullet \bullet$ & Normal graded bedding \\
\hline 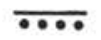 & Reverse graded bedding \\
\hline 0000 & Convolute and contorted bedding \\
\hline II & Water-escape pipes \\
\hline- & Mudcracks \\
\hline & Sharp contact \\
\hline a & Scoured, sharp contact \\
\hline & Gradational contact \\
\hline 7 & Imbrication \\
\hline & Fining-upward sequence \\
\hline & Coarsening-upward sequence \\
\hline & Interval over which a specific structure occurs in core \\
\hline s & Bioturbation-minor $(0-30 \%$ of surface area $)$ \\
\hline 18 & Bioturbation-moderate $(30-60 \%$ of surface area) \\
\hline$M 3$ & Bioturbation-strong (more than $60 \%$ of surface area) \\
\hline $\operatorname{sos}$ & Burrows \\
\hline
\end{tabular}

Figure 9. Symbols of sedimentary structures used on core description forms for sediments.

tion on these forms, where two numbers separated by a hyphen refer to the section and centimeter interval, respectively, of the sample. The locations of these samples in the core and a key to the codes used to identify these samples are given in the column headed "sam- ples" (Fig. 7). Locations and intervals of organic geochemistry (OG) and interstitial water (IW) samples are given in the lithology column.

\section{Lithologic Classification of Sediments}

The basic classification system used here was devised by the JOIDES Panel on Sedimentary Petrology and Physical Properties (SPPP) and adopted for use by the JOIDES Planning Committee in March 1974. For the sake of continuity the Leg 70 shipboard scientists have used this basic classification with some minor modification. We will point out our differences from the SPPP classification when those topics are discussed. The general classification (which embraces several lithologies not encountered during Leg 70) is outlined below.

This classification is descriptive, and divisions between different types of sediment are somewhat arbitrary. We treat lithologic types not covered in this classification as a separate category termed "Special Sediment Types."

The sediments recovered on Leg 70 were composed of biogenic components and hydrothermal sediments (Fig. 10).

\section{Composition and Texture}

In this classification composition and texture are the only criteria used to define the type of sediment or sedimentary rock. Composition is most important for describing sediments deposited in the open ocean, while texture becomes significant for hemipelagic and nearshore sediments. These data come principally from visual estimates of smear slides using a petrographic microscope. They are estimates of areal abundance and size components on the slide and may differ somewhat from more accurate analyses of grain size, carbonate content, and mineralogy (see "Special Studies" section). From past experience, quantitative estimates of distinctive minor components are accurate to within 1-2\%, but for major constituents accuracy is poorer, $\pm 10 \%$. All smear slide estimates were done on board. Carbonate content is difficult to estimate from smear slides. Therefore, for many cores we determined the percentage of carbonate using the "carbonate bomb" technique of Müller and Gastner (1971). This method involves treating a powdered sample with $\mathrm{HCl}$ in a closed cylinder. The resulting pressure of $\mathrm{CO}_{2}$ is proportional to the carbonate $\left(\mathrm{CaCO}_{3}\right)$ content of the sample, and this value is converted to percent $\mathrm{CaCO}_{3}$ using the calibration factor of the manometer. The accuracy of this method is $\pm 5 \%$. Carbonate content determined in this manner is listed on the core description forms below the lithologic description.

Textures of sediments estimated from smear slides and listed as percent sand-silt-clay in the smear slide summary on the core description forms include all constituents. Thus, a diatomaceous ooze will have a greater percentage of silt-size particles than a nannofossil ooze because of the different sizes of the tests of the two planktonic groups. This convention causes some confusion when naming terrigenous sediments that contain a significant number of microfossils. For example, a 
Special Sediment Types

Pelagic

Nonbiogenic

pelagic clay

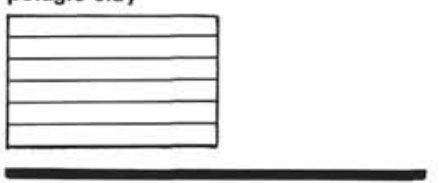

Siliceous Biogenic

Pelagic Siliceous Biogenic - Soft

diatom ooze

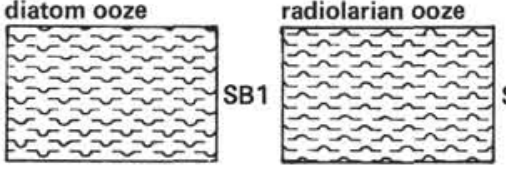

Vertical bar percent

(\%) designation

for graphic log.

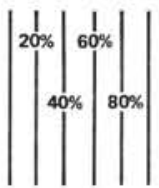

Diatom-rad or siliceous ooze

SB2

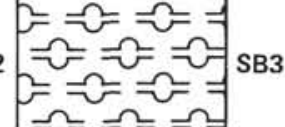

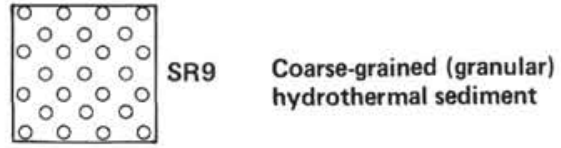

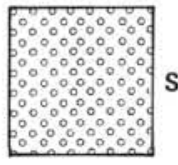

SR10 Fine-grained

hydrotharmal sediments

$M M M$

M M M SR11 Mn-oxide crust M M M fragments

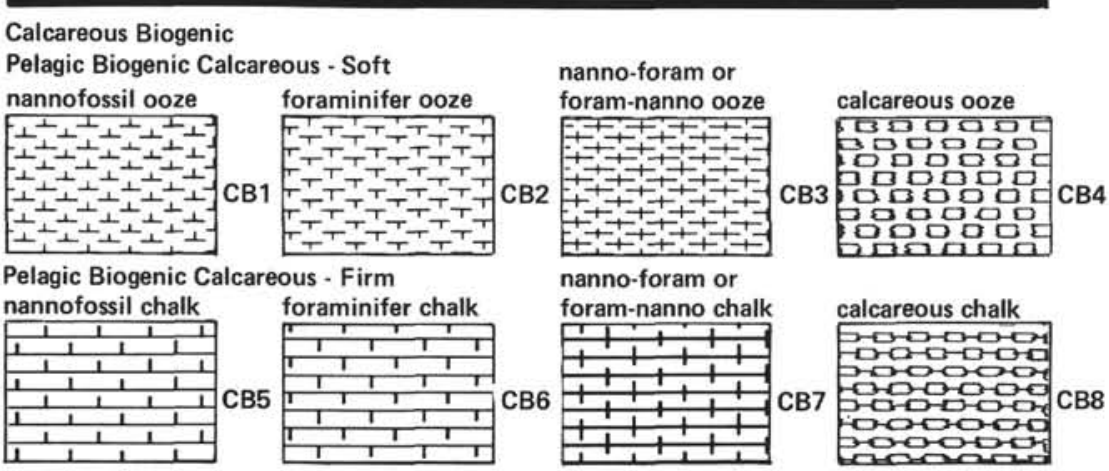

Burrows

$\mathbf{P}=$ Planolites

$\mathrm{Z}=$ Zoophycus

$\mathrm{H}=$ Halo

$\mathrm{C}=$ Chondrites

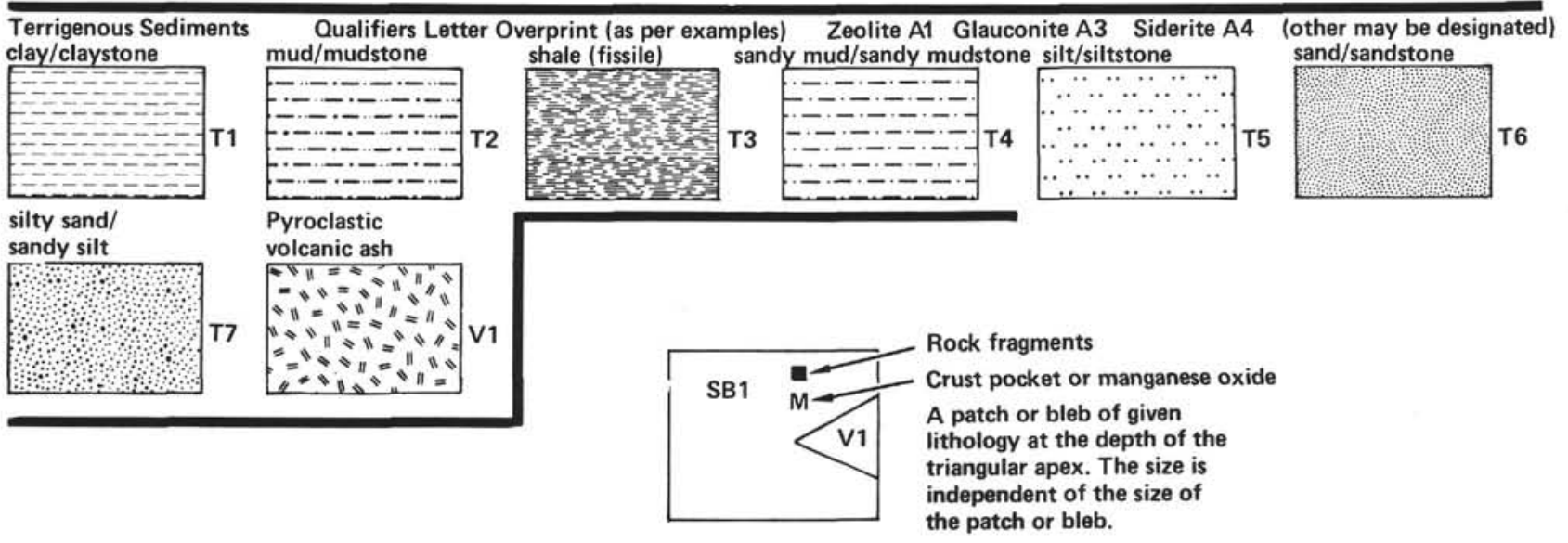

Figure 10. Symbols used in graphic lithology column of core description forms (sediment and HPC).

diatomaceous silty clay may have fewer silt-size terrigenous particles (e.g., quartz and feldspar) than a nannofossil silty clay simply because many diatoms are siltsize and are included as such in the textural estimate. However, we have chosen fairly broad compositional class boundaries (see below) for mixed terrigenous and biogenic sediments in order to minimize this effect. For this reason we preferred to replace the terms "clayeysilt" or "silty-clay" by simply "mud" when used with a biogenic modifier.

Where applicable we used one or several modifiers in naming the type of sediment encountered. In all cases the dominant component appears last in the name, minor components precede with the least common constituent listed first. If the minor constituents occur in amounts less than $10 \%$ they are not included in the name. This convention also holds for zeolites, Fe- and $\mathrm{Mn}$ micronodules, and other indicators of very slow rates of sedimentation or nondeposition such as fish bones. Often these materials are conspicuous even though greatly diluted. If deemed important and environmentally significant, as nontronite, montmorillonite, and smectite were on Leg 70, they are sometimes included in the name of the sediment or mentioned in the lithologic description. 

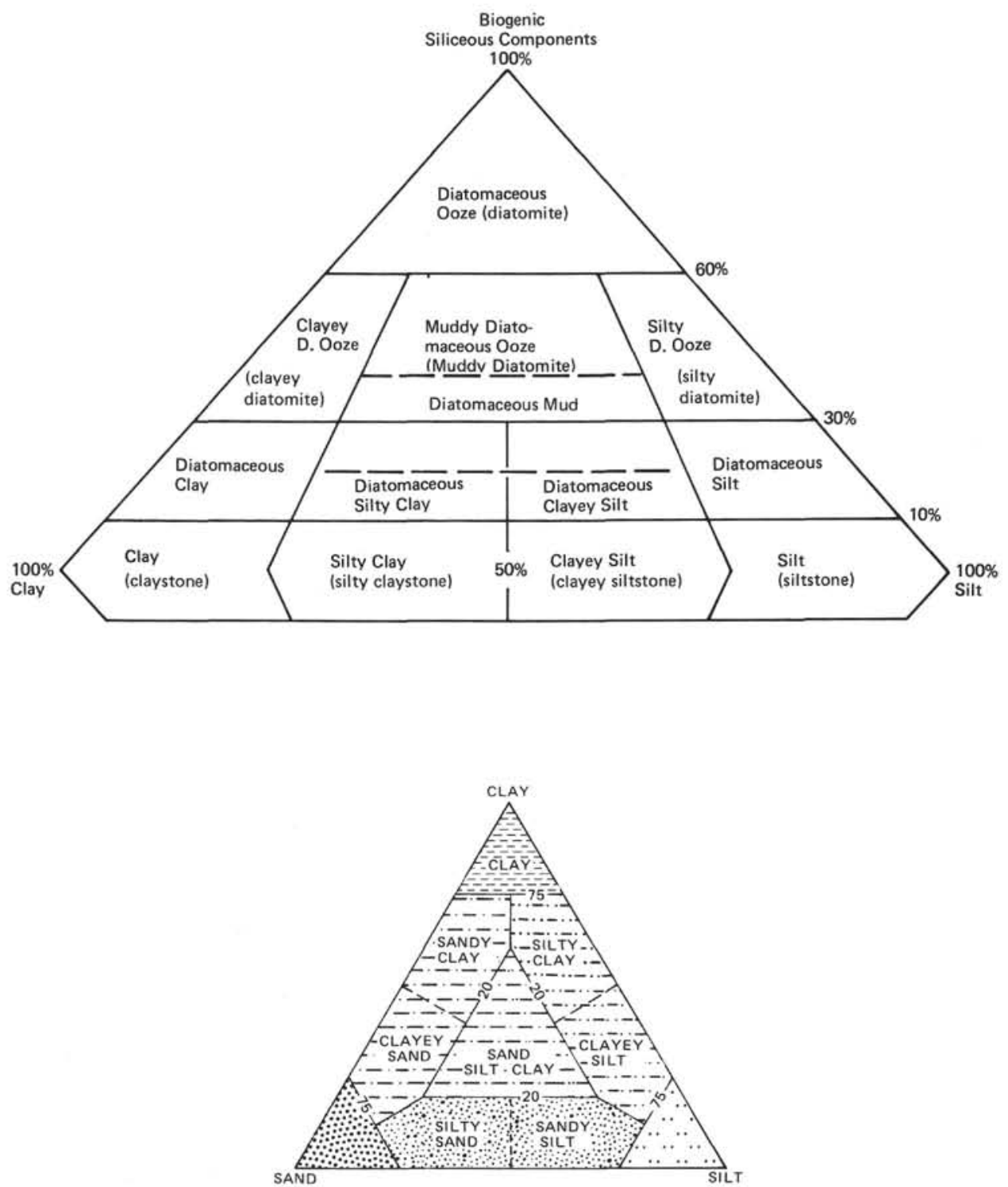

Figure 11. Hemipelagic and textural classification of clastic sediments (Shepard, 1954).

\section{Induration of Sediments}

We recognize three classes of induration or lithification for calcareous sediments and sedimentary rocks in which the carbonate content is greater than $50 \%$ and only two classes for all other lithologic types:

1) Calcareous sediments and sedimentary rocks; categories after Gealy et al. (1971).

(a) Soft $=$ ooze; has little strength and readily deformed under pressure of finger or broad blade of spatula.

(b) Firm = chalk; partially lithified and readily scratched with fingernail or edge of spatula.

(c) Hard = limestone; dolostone; well lithified and cemented; resistant or impossible to scratch with fingernail or edge of spatula.

2) Siliceous sediments (silica $>50 \%$ )

(a) Soft $=$ ooze; readily deformed by finger or broad blade of spatula. (b) Hard = radiolarite, diatomite, chert, or porcellanite; core must be cut with band saw or diamond saw.

3) Terrigenous sediments (terrigenous components $>50 \%$ ).

(a) Soft $=$ sand, silt, clay (or combinations of these); readily deformed by finger or broad blade of spatula.

(b) Hard = sandstone, siltstone, claystone, etc. (i.e., suffix "stone" added); core must be cut with band saw or diamond saw.

\section{Types of Sediments and Compositional Class Boundaries}

We distinguish five basic types of sediment: siliceous biogenic, calcareous biogenic, terrigenous, volcanogenic and pyroclastic, and hemipelagic. Each type of sediment is discussed briefly below. An additional category, 
“Special Sediment Types," used extensively on Leg 70, is also included.

\section{Siliceous Biogenic Sediments}

These are sediments in which biogenic silica or authigenic silica (opal-CT and/or quartz) composes at least $30 \%$ of the sediment. If the siliceous component is between 30 and $60 \%$, then the terrigenous (mud), calcareous biogenic, or volcanogenic modifier is retained. For example, "muddy diatomaceous ooze"' describes a soft sediment with at least $10 \%$ clayey silt and between 50 and $90 \%$ diatoms. If the siliceous component exceeds $60 \%$, then the modifier(s) are dropped. A radiolarian ooze would have $<10 \%$ clay or carbonate and $>60 \%$ radiolarians. If the siliceous biogenic component is between 30 and $60 \%$, then the names for terrigenous or calcareous biogenic sediments or pyroclastic rocks apply, with the dominant siliceous constituent as a qualifier. Silica in amounts $<10 \%$ is not acknowledged in the name. No hard siliceous rock was recovered on Leg 70 . However, for completeness Figure 11 shows a standard DSDP classification.

\section{Calcareous Biogenic Sediments}

These are sediments in which biogenic carbonate or carbonate of indeterminate origin (cement or recrystallized carbonate) composes at least $30 \%$ of the sediment. If the carbonate component is between 30 and $60 \%$, then the terrigenous, siliceous biogenic, or volcanogenic modifiers are retained. For example, "muddy nannofossil ooze" describes a soft sediment with at least $10 \%$ clay and between 30 and $60 \%$ calcareous nannofossils. A nannofossil ooze would have $<10 \%$ clay or silica and $60 \%$ calcareous nannofossils. If the calcareous biogenic component is between 30 and $60 \%$, then the names for terrigenous or siliceous biogenic sediments or pyroclastic rocks apply, with the dominant calcareous constituent as a qualifier. Carbonate less than $10 \%$ is not acknowledged in the name.

For firm and hard calcareous rock with carbonate contents $>50 \%$, the terms chalk, limestone, and dolostone, respectively, apply. If the carbonate content is between 30 and $60 \%$, the terrigenous modifier is retained. The modifiers are dropped when the carbonate content exceeds $60 \%$. If the carbonate content is less than $30 \%$, the terrigenous, siliceous biogenic, or volcanogenic names apply, with the dominant carbonate type retained as a qualifier. Carbonate is not acknowledged in the name if it is present in amounts $<10 \%$.

\section{Terrigenous Sediments}

No terrigenous sediments were recovered on Leg 70 . However, for completeness Figure 11 shows a standard DSDP classification.

\section{Volcanogenic and Pyroclastic Sediments}

We arbitrarily distinguish pyroclastic rocks from volcanogenic sediments using $50 \%$ as the pivotal percentage-pyroclastic rocks having $>50 \%$. Wentworth and Williams' (1932) textural and compositional classifica- tion applies for the pyroclastic rocks. Textural groups are:

$>32 \mathrm{~mm}$-volcanic breccia

4-32 $\mathrm{mm}-$ volcanic lapilli (lapilli tuff when indurated)

$<4 \mathrm{~mm}-$ volcanic ash (tuff when indurated)

The compositional breakdown is vitric (glass), crystalline, or lithic according to the most common constituent. Qualifiers are used when volcanic components form between 50 and $90 \%$ of the sediments. For example, a clayey vitric ash contains $>10 \%$ clay and 50 to $90 \%$ ash composed mainly of glass shards. Terrigenous and biogenous modifiers are dropped if $<10 \%$.

When the volcanic component is $<50 \%$, the terminology and class boundaries for terrigenous (and, less often, biogenic) sediments apply. The modifier "tuffaceous" encompasses both ash and lapilli when either or both of these components occur in amounts between 10 and $50 \%$. Thus, a tuffaceous clayey sand(stone) contains 10 to $50 \%$ ash and/or lapilli and 50 to $90 \%$ clayey sand.

\section{Hemipelagic Sediments}

No hemipelagic sediments were recovered on Leg 70 . However, for completeness Figure 11 (top) shows a standard DSDP hemipelagic classification.

\section{Special Sediment Types}

The special sediment types from Leg 70 are classified as hydrothermal sediments. They are divided into two groups: manganese-oxide crust fragments and nontronitic clay granules. A description of each is found in the preliminary results section, and on each individual HPC barrel sheet. The symbols used for the hydrothermal sediments are found in Figure 10.

\section{Biostratigraphy}

Planktonic foraminifers and calcareous nannofossils were the most abundant taxa observed in the pelagic oozes and therefore are the primary microfossils used to determine the ages of sediments (Fig. 12). The biostratigraphic zonation of planktonic foraminifers follows the scheme of Kaneps (1973). The calcareous nannofossil biostratigraphy follows the zonation proposed by Martini (1971) and the revised zonation of the Pleistocene by Gartner (1977).

\section{Special Studies of Sediments}

\section{Organic Carbon and Carbonate Content}

Measurements of organic carbon made on selected samples were done on board using the Hewlett-Packard $\mathrm{CHN}$ analyzer. In addition we selected samples to be analyzed at the DSDP Sediment Laboratory on a LECO WR-12 carbon analyzer. Some of the data were not available at the time of this compilation.

Organic carbon and carbonate content was determined on board using the "carbonate bomb" method already described. These data appear on the core de- 


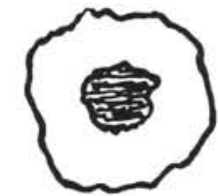

Hollow Cylindrichnus

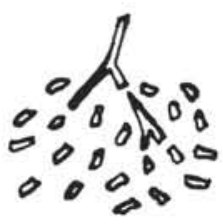

Chondrites

D)DDDDDDDDDDDDSD

Pelleted Zoophycos
Simple Zoophycos

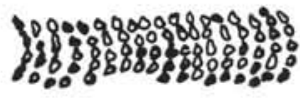

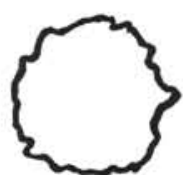

Solid Cylindrichnus

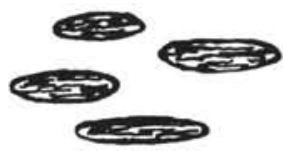

Planolites

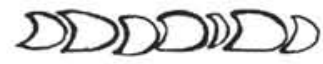

Fat Zoophycos

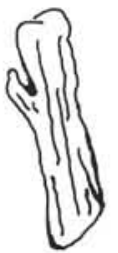

Pyrite Burrows
Figure 12. Most common trace fossils in DSDP cores.

scription forms as, respectively, "\% organic carbon" and " $\% \mathrm{CaCO}_{3}$."

\section{Grain Size Analysis}

Sediment samples selected for grain size analyses to be done at the DSDP Sedimentary Laboratory using standard sieve and pipette methods were not available at the time of this compilation.

\section{X-Ray Diffraction}

An X-ray diffraction unit was for the first time on board the Glomar Challenger. On-board XRD preliminary results are summarized in a table at the end of each site chapter.

\section{IGNEOUS ROCKS}

\section{Visual Core Description Forms}

All igneous rocks were split using a rock saw into working and archive halves described and sampled aboard ship. Figure 13 shows a composite visual core description form used for the description of igneous rocks recovered on Leg 70 . On this form, each section of a core is described under a set of five column headings: (1) piece number, (2) graphic representation, (3) orientation, (4) shipboard studies, and (5) alteration.
In the graphic representation column each piece is accurately drawn and different features, such as texture, glassy margins, or vesicles, coded according to the symbols given in Figure 14. Two closely spaced horizontal lines in this column indicate the location of Styrofoam spacers taped between pieces inside the liner. Each piece is numbered sequentially for the entire leg from the top of the first section beginning with the number 1 and continuing in order until the last piece of igneous rock is recovered at the end of the leg. A total of 1566 pieces of basalt were labeled on Leg 70 . Spacers were placed only between pieces which did not fit together; those pieces were given different numbers. In general, spacers may or may not indicate missing material (not recovered) between pieces. All cylindrical pieces longer than the diameter of the liner have arrows in the "orientation" column indicating that top and bottom have not been reversed as a result of drilling and recovery. Arrows also appear on the labels of these pieces on both archive and working halves.

The column marked "Shipboard Studies" designates the location and the type of measurements made on a sample aboard ship. The column headed "Alteration" gives the degree of alteration using the code given in Figure 14. Below each set of five descriptive columns is the designation for core and section for which these data apply.

Figure 13 gives the outline for core descriptions of igneous rocks in the right-hand margin of the Visual Core Description Form. If more than one core appears on the core form these data are listed below the description of the first core using the same format. As many cores as space allows are included on one visual core description form. When space for descriptions is inadequate on this form, these data appear on the following or facing page. However, in no case does information from one core appear on successive core forms.

For each core, the core number, sections, and depth interval recovered are listed followed by the major and minor rock types and a short description. Thin section data are tallied below this, then shipboard data.

\section{Classification of Igneous Rocks}

We informally classified igneous rocks recovered on Leg 70 according to mineralogy and texture determined from visual inspection of hand specimen and thin sections. The following conventions were agreed upon while at sea, and we realize that they are generalizations. It is possible that gradations may exist within and among textural groups in a single sample.

Quench textures recognized and described include:

1) Glassy-matrix is basaltic glass with no visible incipient crystallization.

2) Variolitic-texture characterized by the presence of varioles, which are spherical bodies, usually consisting of radiating plagioclase and/or clinopyroxene microlites or crystals; individual crystals are indistinguishable with the microscope.

3) Subvariolitic-texture in which varioles coalesce.

4) Immature Sheaf - a bundled arrangement of small crystals (which cannot be individually distinguished 


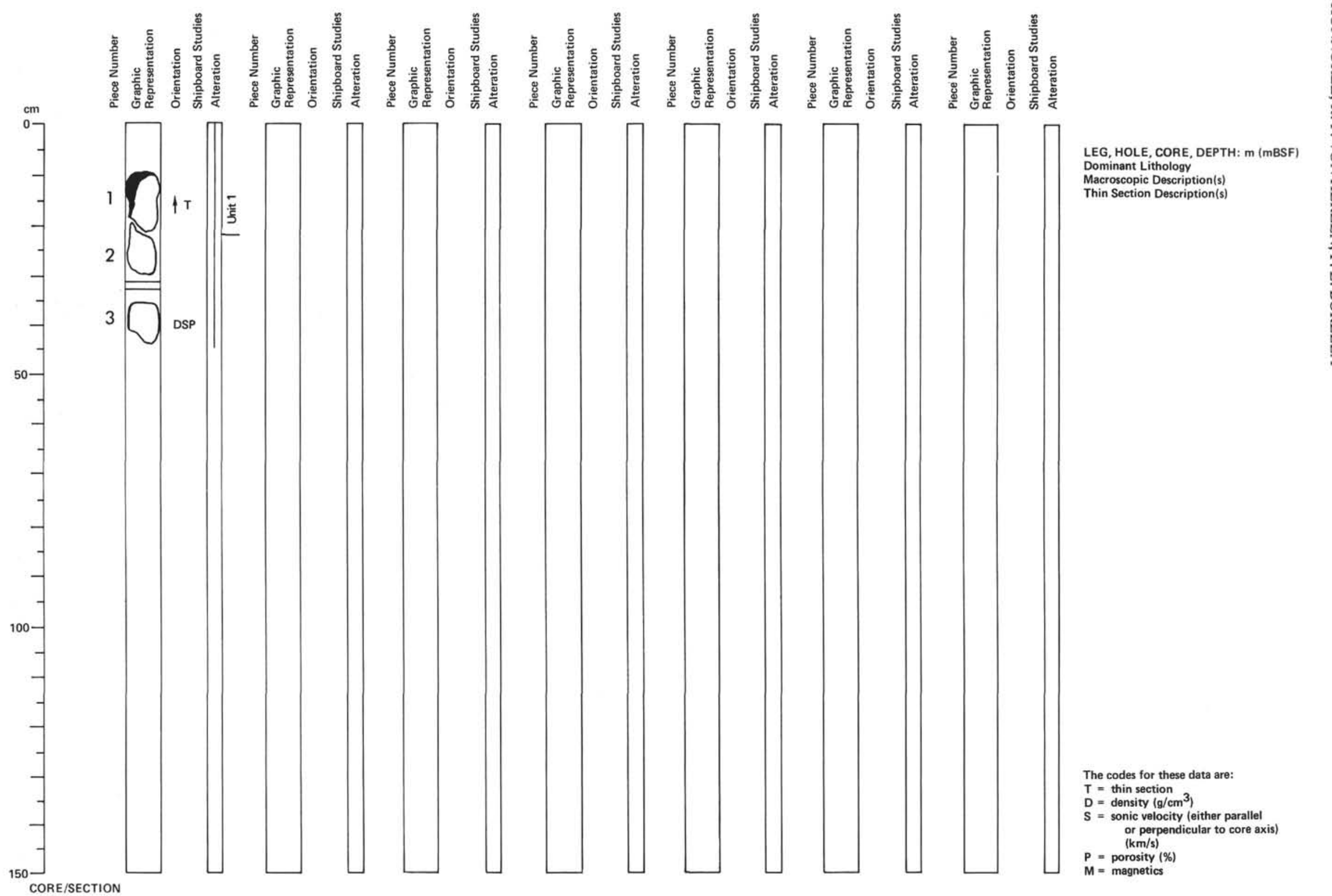

Figure 13. Visual core description form for igneous rocks. 


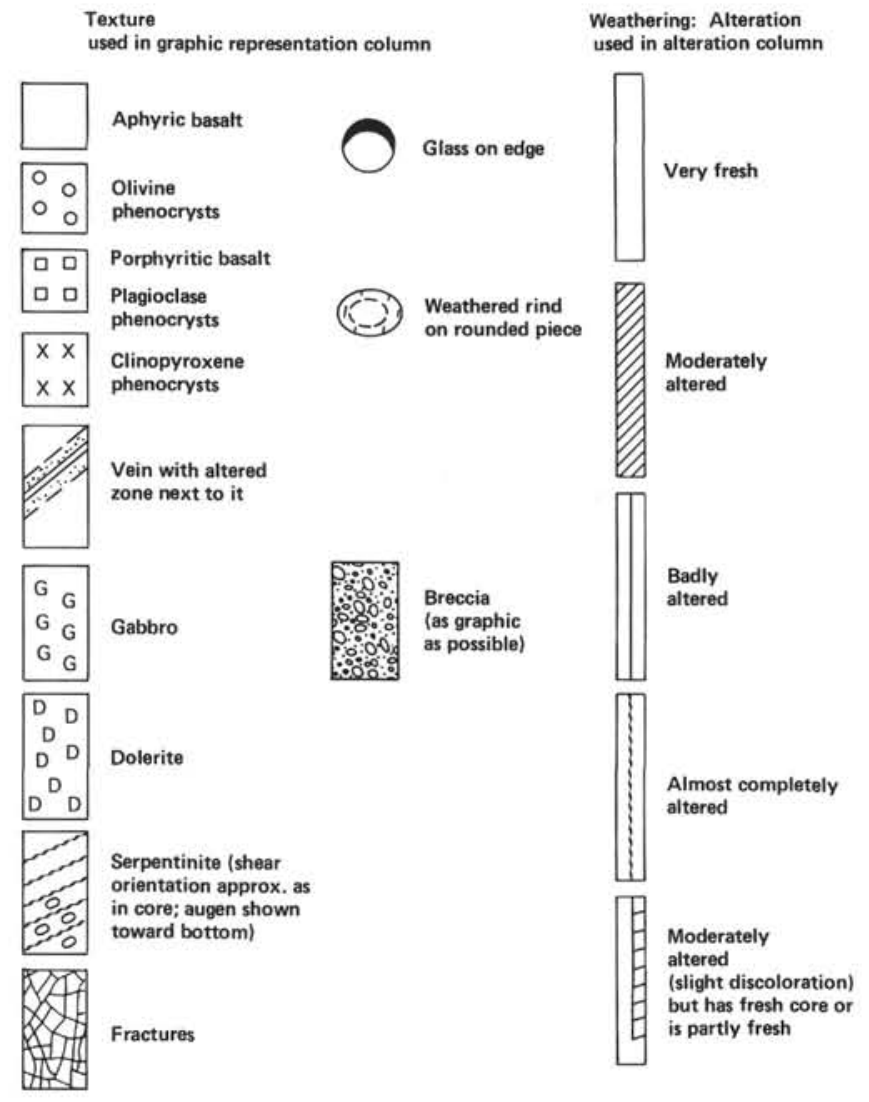

Figure 14. List of symbols for igneous rocks.

with the microscope) assuming a sheaf-life appearance; a central axis of crystal growth often occurs.

5) Mature Sheaf-same as above, but discrete skeletal crystals can be distinguished with the microscope (usually greater than $0.005 \mathrm{~mm}$ wide).

6) Plumose-plume- or feather-like arrangement of microlites or crystals; may grade from immature to mature (as in sheaf texture) because of crystal size.

Major textural classification for basaltic samples used during Leg 70 include:

1) Phyric-a term describing igneous rocks in which larger crystals (phenocrysts) are set in a finer groundmass, which may be crystalline, or glassy, or both.

Aphyric: no phenocrysts

Sparsely phyric: $1-2 \%$ phenocrysts

Moderately phyric: $2-10 \%$ phenocrysts

Highly phyric: $>10 \%$ phenocrysts

2) Glomerophyric - a term applied to phyric rocks containing clusters of equant crystals larger than the matrix crystals.

3) Ophitic-a term applied to a characteristic of texture in which euhedral or subhedral crystals of plagioclase are embedded in a mesostasis of pyroxene crystals.

4) Subophitic-said of the ophitic texture of an igneous rock in which the feldspar crystals are approximately the same size as the pyroxene and are only partially included by them.

5) Intergranular-a term applied to volcanic rocks in which there is an aggregation of grains of clinopyrox- ene, not in parallel optical continuity (as in subophitic texture), between a network of feldspar laths which may be diverse, subradial, or subparallel. Intergranular texture is distinguished from an intersertal texture by the absence of interstitial glass or other quenched phases which may fill the interstices between the feldspar laths.

6) Intersertal-a term applied to volcanic rocks in which a base of mesostasis or glass and small crystals fills the interstices between unoriented feldspar laths, the base forming a relatively small proportion of the rock. When the amount of the base increases and the feldspar laths decrease, the texture becomes hyalophitic, and with still greater increase in the amount of the base, the texture becomes hyalopilitic.

Paleomagnetic data taken on board are not listed but will appear in a more comprehensive study by shipboard scientists.

\section{PHYSICAL PROPERTIES}

Boyce (1976) describes in considerable detail the equipment, methods, and corrections routinely used by shipboard scientists to measure physical properties of sediments and rocks recovered at DSDP sites. On Leg 70 we determined saturated bulk density using the gamma-ray attenuation porosity evaluator (GRAPE) and the gravimetric technique porosity calculated from GRAPE and gravimetric measurement, water content from gravimetric measurements, sonic velocity using the Hamilton Frame velocity meter, and shear strength of undisturbed sediments (see Boyce 1977). For density and porosity calculations we assume grain densities of $2.70 \mathrm{~g} / \mathrm{cm}^{3}$ for sediments and $2.90 \mathrm{~g} / \mathrm{cm}^{3}$ for igneous rocks and a corrected pore fluid density of $1.128 \mathrm{~g} / \mathrm{cm}^{3}$. Listings of these corrected data are available on request from Deep Sea Drilling Project.

\section{PHOTOGRAPHY}

As supplements to the core descriptions, sets of color and black-and-white slides and photographs of whole cores are available for consultation at both repositories. In addition, negatives in color and black and white for close-up documentation of special structures are archived at DSDP. Table 3 lists those from Leg 70.

\section{REFERENCES}

Allmendinger, R. W., and Riis, F., 1979. The Galapagos Rift at $86^{\circ} \mathrm{W}$ : Regional morphological and structural analysis. J. Geophys. Res., 84:5379-5389.

Anderson, R. N., Clague, D. A., Klitgord, K. D., Marshall, M., and Nishimori, R. K., 1975. Magnetic and petrologic variations along the Galapagos spreading center and their relation to the Galapagos melting anomaly. Bull. Geol. Soc. Am., 86:683-694.

Bischoff, J. L., 1972. A ferroan nontronite from the Red Sea geothermal system. Clays Clay Miner., 20:217-223.

Boyce, R. E., 1976. Definitions and laboratory techniques of compressional sound velocity parameters and wet-water content, wetbulk density, and porosity parameters by gravimetric and gamma ray attenuation techniques. In Schlanger, S. O., Jackson, E. D., et al., Init. Repts. DSDP, 33: Washington (U.S. Govt. Printing Office), 931-958.

1977. Deep Sea Drilling Project procedures for shear strength measurement of clayey sediment using modified Wykeham Farrance laboratory vane apparatus. In Barker, P. F., Dalziel, I. W. D., et al., Init. Repts. DSDP, 36: Washington (U.S. Govt. Printing Office), 1059-1068. 
Corliss, J. B., Dymond, J. R., Gordon, L. I., Edmond, J. M., Von Herzen, R. P., Ballard, R. D., Green, K., Williams, D. L., Bainbridge, A., Crane, K., and van Andel, Tj. H., 1979a. Submarine thermal springs on the Galapagos Rift. Science, 203:1073-1083.

Corliss, J. B., Gordon, L. I., and Edmond, J. M., 1979b. Some implications of heat/mass ratios in Galapagos Rift hydrothermal fluids for models of sea water-rock interaction and the formation of oceanic crust. In Talwani, M., Harrison, C. G., and Hayes, D. E. (Eds.), Deep Drilling Results in the Atlantic Ocean: Ocean Crust. Am. Geophys. Union, (Maurice Ewing Series 2), 391-402.

Corliss, J. B., Lyle, M., Dymond, J. R., and Crane, K., 1978. The chemistry of hydrothermal sediment mound deposits near the Galapagos rift. Earth Planet. Sci. Lett., 40:12-14.

Edmond, J. M., Measures, C., McDuff, R. E., Chan, L. H., Collier, R., Grant, B., Gordon, L. I., and Corliss, J. B., 1979a. Ridge crest hydrothermal activity and the balances of the major and minor elements in the ocean: The Galapagos Data. Earth Planet. Sci. Lett., 46:1-18.

Edmond, J. M., Measures, C., Mangum, B., Grant, B., Sclater, F. R., Collier, R., Hudson, A., Gordon, L. I., and Corliss, J. B., 1979b. On the formation of metal-rich deposits at ridge crests. Earth Planet. Sci. Lett., 46:19-30.

Gartner, S., 1977. Calcareous nannofossil biostratigraphy and revised zonation of the Pleistocene. Mar. Micropaleon., 2:1-25.

Gealy, E. L., Winterer, E. L.; and Moberly, R., 1971. Methods, conventions and general observation. In Winterer, E. L, Riedel, W. R., et al., Init. Repts. DSDP, 7, Pt. 2: Washington (U.S. Govt. Printing Office), 9-26.

Green, K. E., Von Herzen, R. P., and Williams, D. L., 1981. The Galapagos Spreading Center at $86^{\circ} \mathrm{W}$ : A detailed geothermal field study. J. Geophys. Res., 86(B2):979-986.

Hekinian, R., Rosendahl, B. R., Cronan, D. S., Dmitriev, Y., Fodor, R. V., Goll, R. M., Hoffert, M., Humphris, S. E., Mattey, D. P., Natland, J., Petersen, N., Roggenthen, W., Schrader, E. L., Srivastava, R. K., and Warren, N., 1978. Hydrothermal deposits and associated basement rocks from the Galapagos spreading center. Oceanol. Acta, 1:473-482.

Hey, R., Johnson, G. L., and Lowrie, A., 1977. Recent plate motions in the Galapagos area. Bull. Geol. Soc. Am., 88:1385-1403.

Hoffert, M., Perseil, A., Hekinian, R., Choukroune, P., Needham, H. D., Francheteau, J., and Le Pichon, X., 1978. Hydrothermal deposits sampled by diving saucer in transform fault " $\mathrm{A}$ " near $37^{\circ} \mathrm{N}$ on the Mid-Atlantic Ridge, FAMOUS area. Oceanol. Acta, $1: 73-86$.

Hoffert, M., Person, A., Courtois, C., Karpoff, A. M., and Trauth, D., 1980. Sedimentology, mineralogy and geochemistry of hydrothermal and sedimentary deposits from Holes 424, 424A, 424B, 424C. In Hekinian, R., Rosendahl, B. R., et al., Init. Repts. DSDP, 54: Washington (U.S. Govt. Printing Office), 339-376.

Irving, E., Robertson, W. A., and Aumento, S., 1970. The MidAtlantic Ridge near $45^{\circ} \mathrm{N}, 6$, remanent intensity, susceptibility and iron content of dredged samples. Can. J. Earth Sci., 7:226-238.

Johnson, H. P., and Atwater, T., 1977. A magnetic study of the basalts from the Mid-Atlantic Ridge at $37^{\circ}$ N. Bull. Geol. Soc. Am. $88: 637-642$.

Kaneps, A. G., 1973. Cenozoic planktonic foraminifera from the eastern equatorial Pacific Ocean. In van Andel, Tj. H., Heath, G. R., et al., Init. Repts. DSDP, 16: Washington (U.S. Govt. Printing Office), 713-745.

Klitgord, K. D., and Mudie, J. D., 1974. The Galapagos Spreading Center: A near-bottom geophysical survey. Geophys. J. R. Astron. Soc., 38:563-586.

Lonsdale, P., 1977. Deep-tow observations at the mounds abyssal hydrothermal field, Galapagos Rift. Earth Planet. Sci. Lett., 36: 92-110.

Martini, E., 1971. Standard Tertiary and Quaternary calcareous nannoplankton zonation. In Farinacci, A. (Ed.), Second Planktonic Conf. Proc., Rome (Tecnoscienza), pp. 739-785.

Müller, G., and Gastner, M., 1971. The "Karbonate-Bomb", a simple device for determination of the carbonate content in sediments, soils and other materials. N. Jahrb. Mineral. Mh., 10:466-469.

Natland, J., Rosendahl, B., Hekinian, R., Dmitriev, Y., Fodor, R., Goll, R., Hoffert, M. Humphris, S., Mattey, D., Petersen, N., Roggenthen, W., Schrader, E., Srivastava, R., and Warren, N.,
1979. Galapagos hydrothermal mounds: stratigraphy and chemistry revealed by deep sea drilling. Science, 204:613-616.

Rateev, M. A., Timofeev, N. V., and Renngarten, N. V., 1980. Minerals of the clay fraction in Pliocene-Quaternary sediments of the east equatorial Pacific, Leg 54 Glomar Challenger. Hekinian, R., Rosendahl, B. R., et al., Init. Repts. DSDP, 54: Washington (U.S. Govt. Printing Office), 307-318.

Sclater, J. G., and Klitgord, K. D., 1973. A detailed heat flow, topographic and magnetic survey across the Galapagos Spreading Center at $86^{\circ}$ W. J. Geophys. Res., 78:6951-6975.

Sclater, J. G., Von Herzen, R. P., Williams, D. L., Anderson, R. N., and Klitgord, K., 1974. The Galapagos Spreading Center: Heatflow on the north flank. Geophys. J. R. Astron. Soc., 38:609-626.

Shepard, F. P., 1954. Nomenclature based on sand-silt-clay ratios. $J$. Sediment. Petrol., 24:151-158.

Wentworth, C. K., 1922. A scale of grade and class terms of clastic sediments. J. Geol., 30:377.

Wentworth, C. K., and Williams, H., 1932. The classification and terminology of the pyroclastic rocks. Rept. Comm. Sedimentation, Bull. Nat. Res. Council, 80:10-53.

Williams, D. L., Green, K., van Andel, Tj. H., Von Herzen, R. P., Dymond, J. R., and Crane, K., 1979. The hydrothermal mounds of the Galapagos Rift: Observations with DSRV Alvin and detailed heat flow studies. J. Geophys. Res., 84(B13):7467-7484.

Williams, D. L., Von Herzen, R. P., Sclater, J. G., and Anderson, R. N., 1974. The Galapagos Spreading Center: Lithospheric cooling and hydrothermal circulation. Geophys. J. R. Astron. Soc., $38: 587-608$.

Table 3. Leg 70 detail core photographs (black and white).

\begin{tabular}{|c|c|}
\hline $\begin{array}{l}\text { Negative } \\
\text { Number }\end{array}$ & $\begin{array}{c}\text { Sample } \\
\text { (interval in } \mathrm{cm} \text { ) }\end{array}$ \\
\hline 31 & $506-6-1,95-105$ \\
\hline 32 & $506-6-2,10-25$ \\
\hline 33 & $506 \mathrm{~B}-1-1,20-30$ \\
\hline 34 & $506 \mathrm{~B}-2-1,0-15$ \\
\hline 35 & $506 \mathrm{~B}-2-2,40-65$ \\
\hline 36 & $506 \mathrm{~B}-2-3,20-30$ \\
\hline 37 & $506 \mathrm{~B}-3-2,55-65$ \\
\hline 38 & 506B-3-2, 110-125 \\
\hline 39 & $506 \mathrm{~B}-3-3,5-20$ \\
\hline 40 & $506 \mathrm{C}-1-1,20-30$ \\
\hline 41 & $506 \mathrm{C}-1-2,120-135$ \\
\hline 42 & $506 C-1-3,45-55$ \\
\hline 43 & $506 C-2-1,25-35$ \\
\hline 44 & $506 C-2-1,55-70$ \\
\hline 45 & $506 C-2-2,125-140$ \\
\hline 46 & $506 \mathrm{C}-5-1,30-40$ \\
\hline 47 & $506 \mathrm{C}-5-3,55-70$ \\
\hline 48 & $506 C-6-1,80-90$ \\
\hline 49 & $506 C-6-2,65-75$ \\
\hline 50 & $506 C-6-3,70-80$ \\
\hline 51 & $506 \mathrm{D}-1-1,10-20$ \\
\hline 52 & $506 \mathrm{D}-1-1,70-80$ \\
\hline 53 & $506 \mathrm{D}-1-1,115-130$ \\
\hline 54 & $506 \mathrm{D}-2-3,70-95$ \\
\hline 55 & $506 \mathrm{D}-3-2,60-80$ \\
\hline 56 & $506 \mathrm{D}-6-2,112$ \\
\hline 57 & $506 \mathrm{D}-9-1,48-51$ \\
\hline 58 & $506 \mathrm{D}-9-1,48-51$ \\
\hline 59 & $506 \mathrm{G}-2-1,90-93$ \\
\hline 60 & $506 \mathrm{G}-2-1,90-93$ \\
\hline 61 & $507 \mathrm{~B}-1-1,0-25$ \\
\hline 62 & 507B-1-1, 29-31 \\
\hline 63 & 507B-1-1, 29-31 \\
\hline 64 & $507 \mathrm{~B}-1-1,43-46$ \\
\hline 65 & $507 \mathrm{~B}-1-1,25-50$ \\
\hline 66 & 507B-1-1, Piece 27 \\
\hline 67 & 507C-2-1, Piece 30 \\
\hline 68 & 507C-3-1, Piece 31 \\
\hline 69 & $507 C-3-1,31-35$ \\
\hline 70 & 507D-1-1, 60-90 \\
\hline 71 & $508-2-2,45-70$ \\
\hline 72 & $508-2-2,70-95$ \\
\hline
\end{tabular}

Table 3. (Continued)

\begin{tabular}{cl}
\hline Negative & \multicolumn{1}{c}{ Sample } \\
Number & \multicolumn{1}{c}{ (interval in cm) } \\
\hline & \\
73 & $508-2-3,25-50$ \\
74 & $508-2-3,50-75$ \\
75 & $508-2-3,75-100$ \\
76 & $508 \mathrm{~B}-1-2,30-40$ \\
77 & $508 \mathrm{~B}-3-1$, Piece 38 \\
78 & $508 \mathrm{~B}-3-1$, Piece 39 \\
79 & $508 \mathrm{~B}-3-1$, Piece 40 \\
80 & $508 \mathrm{~B}-3-1$, Piece 42 \\
81 & $509-3-2,75-105$ \\
82 & $509-3-2,110-120$ \\
83 & $509-4-2,60-75$ \\
84 & $509-5-3,0-10$ \\
85 & $509 \mathrm{~B}-1-1,100-125$ \\
86 & $509 \mathrm{~B}-1-2,115-120$ \\
87 & $509 \mathrm{~B}-1-2,115-120$ \\
88 & $509 \mathrm{~B}-1-2,110-130$ \\
89 & $509 \mathrm{~B}-1-2,125-150$ \\
90 & $509 \mathrm{~B}-2-1,15-45$ \\
91 & $509 \mathrm{~B}-2-1,55-85$ \\
92 & $509 \mathrm{~B}-2-1,110-140$ \\
93 & $509 \mathrm{~B}-2-2,30-60$ \\
94 & $509 \mathrm{~B}-2-2,30-60$ \\
95 & $509 \mathrm{~B}-2-3,10-40$ \\
96 & $509 \mathrm{~B}-3-2,40-70$ \\
97 & $509 \mathrm{~B}-3-2,105-135$ \\
98 & $509 \mathrm{~B}-4-2,90-120$ \\
99 & $509 \mathrm{~B}-4-3,60-90$ \\
100 & $510-8, \mathrm{CC}$, Piece 51 \\
101 & $510-8-2,100-102$ \\
102 & $510-9-1$, Piece 54 \\
103 & $510-9-1$, Piece 59 \\
104 & $510-9-1$, Piece 62 \\
105 & $510-9-1$, Piece 66 \\
106 & $510-9-2$, Piece 76 \\
107 & $510-9-2$, Piece 84 \\
108 & $510-9-3$, Piece 91 \\
109 & $510-9-3$, Piece 96 \\
110 & $510-10-1$, Piece 114 \\
111 & $510-10-1,4-6$ \\
112 & $510-11-1,40-43$ \\
113 & $510-11-1,40-43$ \\
& \\
\hline &
\end{tabular}

